\title{
Ukrayna Krizinin Rusya ve Japonya Arasındaki Kuril Adaları Sorununa Etkisi
}

\author{
Emine AKÇADAĞ \\ Yrd. Doç. Dr., Siyaset Bilimi ve Uluslararası İliskiler Bölümü, İstanbul Gelișim Üniversitesi, İstanbul. \\ E-posta:emiakcadag@hotmail.com \\ Elnur İSMAYILOV
}

Ph.D, Uluslararası Politika Bölümü, Westphalian Wilhelms University Münster, Almanya., Küreselleşme ve Demokratik Yönetişim Merkezi (GLODEM), TÜBITAK 2216 Araştırmacısı (2014-2015) Koç Üniversitesi, İstanbul.

E-posta:elnur@gmx.de.

\section{ÖZET}

Asya-Pasifik bölgesindeki en uzun süreli toprak anlaşmazlıklarından biri olan Japonya ile Rusya arasındaki Kuril Adaları/Kuzey Toprakları sorunu, iki ülke arasında İkinci Dünya Savaşı sonrasında bir barış antlaşması imzalanamamış olmasının temel nedenlerindendir. Taraflar arasında SSCB'nin yıkılmasından sonra da pek çok görüşme gerçekleştirilmiş olmasına rağmen bir mutabakat sağlanamamıştır. Son dönemde, Aralık 2012'de göreve gelen Japonya Başbakanı Şinzo Abe'nin sorunun çözümü ve ilişkilerin geliştirilmesi için sarf ettiği çabalar tam meyve vermeye başladığı sırada yaşanan 2014 Ukrayna krizi olumlu gelişmeleri ciddi biçimde sekteye uğratmıştır. Bu çalışmanın amacı, zaman zaman karşılıklı provokatif nitelikli gelişmelere yol açan Ukrayna krizine rağmen Moskova ve Tokyo'yu ihtilaflı adalar sorunun çözümüne iten sistemsel ve iç etmenleri ortaya koymaktır.

Anahtar Kelimeler: Japonya, Kuril Adaları, Kuzey Toprakları, Rusya, Ukrayna Krizi

\section{The Impact of the Ukraine Crisis on the Kuril Islands Dispute between Russia and Japan}

\begin{abstract}
The Kuril islands/Northern Territories dispute between Russia and Japan which represents one of the longest standing territorial disputes in the Asia-Pacific region, is also one of the main reasons for the inability to sign a peace treaty since the end of World War II. Despite the conduct of many negotiations between two parties after the collapse of the USSR, a consensus has not been achieved so far. The efforts of Shinzo Abe who took office in December 2012 to solve the dispute and to develop friendly relations began to bear fruits. However, the 2014 Ukraine crisis has seriously disrupt this positive development. The aim of this study is to investigate the systemic and domestic factors which pushed Moscow and Tokyo for a political solution of this dispute, despite the existence of some provocative steps within the context of the Ukraine crisis.
\end{abstract}

Keywords: Japan, Kuril Islands, Northern Territories, Russia, Ukraine crisis 


\section{Giriş}

İkinci Dünya Savaşı'nın bitiminden beri süregelen Kuril Adaları/Kuzey Toprakları sorunu, Rusya ile Japonya arasında bir barış antlaşması imzalanarak ilişkilerin normalleşmesinin önündeki temel engellerden biridir. Kuril ada grubu Rusya'nın Kamçatka ile Japonya'nın Hokkaido bölgeleri arasında bulunmakta olup $1.250 \mathrm{~km}$ uzunluğundadır. Japonya ile Rusya arasında anlaşmazlık teşkil eden ve Rusya tarafından Güney Kuril Adaları, Japonya tarafından Kuzey Toprakları olarak adlandırılan adalar Kuril ada grubunun güneyindeki Kunaşir (Japonca Kunaşiri), Iturup (Japonca Etorofu), Habornai ve Şikotan'dır. Söz konusu dört adanın toplam yüz ölçümü $5.038,33 \mathrm{~km}^{2}$ olup Habornai ve Şikotan bu alanın sadece \%6'sını oluşturmaktadır. Adaların jeostratejik, ekonomik ve sembolik önemi, Rusya'nın ilk Cumhurbaşkanı Boris Yeltsin döneminden itibaren karşılıklı görüşmeler yapılmasına rağmen sorunun çözülememesinde etkendir.

Kuril Adaları/Kuzey Toprakları sorununun çözümü, Aralık 2012'de Japonya'da göreve gelen Başbakan Şinzo Abe'nin öncelikli dış politika hedeflerinden biridir. Abe, pek çok defa Rus mevkidaşı Vladimir Putin ile bir araya gelerek ilişkileri geliştirmek, karşılıklı güveni tesis etmek ve Kuril/Kuzey Toprakları sorununu çözmek içim girişimlerde bulunmuştur. Ancak ikili ilişkilerde uzun yıllar sonra yakalanan bu olumlu hava, Rusya'nın Ukrayna toprağı Kırım Özerk Cumhuriyeti'ni ilhak etmesi sonucu Batı'nın tepki olarak yürürlüğe koyduğu yaptırımları Japonya'nın da benimsemesiyle dağılmaya başlamıştır. Gerek Kremlin'in söylemleri gerekse tartışmalı adalarda Rus ordusu tarafından gerçekleştirilen askeri tatbikat Rusya'nın tutumunu gözler önüne serse de Tokyo siyasi diyaloğun devam ettirilmesi ve ihtilafın çözümü için yapıcı adımların atılması gerektiğini dile getirmektedir.

Devletlerin izlediği dış politika genel olarak uluslararası sistemin yapısından etkilense de özellikle anlaşmazlık ve kriz durumlarında iç faktörler ve karar alıcıların düşünce ve hassasiyetleri de göz ardı edilmemesi gereken faktörlerdir. Günümüzde ülkelerin izledikleri dış politikaları açıklamakta en fazla başvurulan teori olan realizm, devlet adamlarının dış politikalarında zaman zaman neden realist öngörülere uymadıklarını açıklamakta yetersiz kalmaktadır. ${ }^{1}$ Kuril Adaları Sorunuyla ilgili olarak Rusya ve Japonya’nın izlediği dış politikanın analizi, gerek uluslararası koşullar gerekse iç siyasal imkân ve kısıtlamaların göz önünde bulundurulmasını gerektirdiğinden bu konu neo-klasik realizm çerçevesinde ele alınmaya çalışılacaktır. Gideon Rose'un 1998'de World Politics'de yayımladığı makaleyle öncülüğünü yaptığı neo-klasik realizm kuram, hem dış hem de iç değişkenleri bünyesinde barındırarak klasik realizmi güncellemekte ve ona sistemsel unsurları adapte etmektedir. Rose konuyu şu şekilde açıllamaktadır:

Bir ülkenin dış politikasının kapsamı ve amaçlarının öncelikle onun uluslararası sistem içindeki yeri ve özellikle göreceli şekilde sahip olduğu maddi güç unsurları tarafından belirlendiğini ifade etmektedir. Bu onları realist yapan şeydir. Bununla birlikte bu güç unsurlarının dış politika üzerindeki etkisi dolaylı ve karmaşıktır çünkü sistemin baskısı birey düzeyindeki çeşitli değişkenler yoluyla etkinliğini hissettirmektedir. Bu da onları neorealist yapan şeydir. ${ }^{2}$

Neoklasik realizm uluslararası sistemi önemli bir değişken olarak görmekle birlikte dış politikaların söz konusu yapısal faktörlerin, birim (devlet) seviyesindeki aracı değişkenlerin

1 Mustafa Aydın, "Uluslararası İlişkilerin Gerçekçi Teorisi: Kökeni, Kapsamı, Kritiği”, Uluslararası İlişkiler, Cilt 1, Sayı 1, Bahar 2004, s.57.

2 Gideon Rose, "Neoclassical Realism and Theories of Foreign Policy", World Politics, Cilt 51, No.1, 1998, s.152. 
süzgecinden geçirilerek oluşturulduğunu savunmaktadır. ${ }^{3} \mathrm{Bu}$ aracı değişkenler devletlerin iç yapılarına ait değişkenler olup kesin bir tanımlaması olmamakla birlikte liderlerin algılamaları ve devletlerin kendilerine ait iç yapılarında yer alan özellikleri kapsamaktadır. Dolayısıyla neo-klasik realistler hem sistemin baskısını hem de iç siyasal düzen ve karar alıcıların düşünce ve davranışları gibi birey düzeyindeki değişkenleri analiz etmek amacındadır.

Randall Schweller ${ }^{4}$, Fareed Zakaria ${ }^{5}$, Thomas Christensen ${ }^{6}$ ve William Wohlforth ${ }^{7}$ gibi isimlerin çalışmaları sonucu gelişen bu kuram, analiz düzeyi olarak sadece sistemi değil aynı zamanda devlet ve bireyi de ele almaktadır. Süre gelen anlaşmazlıklar ve bilhassa bu anlaşmazlıkların zaman zaman yol açtığı kriz dönemlerinde devletlerin izlediği dış politika incelenirken uzun dönemde sonuçları görülebilecek güç kapasitesi veya sistemsel değişimler gibi unsurların yanında kısa vadeli tepki ve davranışların ardında yatan sebeplerin de değerlendirmeye katılması söz konusu politikanın daha iyi anlaşılması açısından önemlidir. Bu tepki ve davranışların incelenmesi ise iç siyasal yapıların ve karar alıcıların dikkate alınmasını gerekli kılmaktadır. Neo-klasik realizmin temsilcilerinden Fareed Zakaria, devletlerin değil devlet adamlarının uluslararası ilişkilerdeki temel aktörler olduğunu ifade etmektedir. ${ }^{8}$

Bu bağlamda, Kuril sorunu çerçevesinde Tokyo ve Moskova'nın Şinzo Abe’nin başbakanlık görevine geldiği Aralık 2012'den Ukrayna krizinin ertesine kadar izlediği politikalar irdelenirken Kuzeydoğu Asya bölgesinin konjonktürü, Japon ve Rus toplumunun düşünce ve beklentileri, Abe ve Putin'in tutum ve hassasiyetleri, farklı çıkar gruplarının bakış açısı üzerinde durulacaktır. Böylelikle hem sistemsel hem de iç faktörler bir arada ele alınarak ikili ilişkilerin gelişimi ve ihtilaflı adalar sorunu ile ilgili daha kapsamlı bir analiz yapılması hedeflenmektedir.

\section{Adaların Aidiyetine İlişkin Tarafların İddiaları}

18. yüzyılda hem Rus hem Japon kâşifler Kuril Adaları́na ayak basmış ve iki ülke arasında adaların hâkimiyeti sorunu böylece ortaya çıkmıştır. Bu sorunu aşmak ve bir sınır belirlemek amacıyla taraflar, 7 Şubat 1855 'te Japonya’nın Şimoda şehrinde imzaladıkları Şimoda Anlaşması ile bölgeyi paylaşmışlardır. Buna göre Kuril Takımadalarının ortasından yani Urup Adaları́ndan itibaren kuzeydeki bütün adalar Rusya’ya, güneydekiler (dört ada dahil) ise Japonya’ya verilmiştir.

3 Ibid., s.146

4 Randall L. Schweller, Deadly Imbalances: Tripolarity and Hitlers Strategy of World Conquest, New York, Columbia University Press, 1998.

5 Fareed Zakaria, From Wealth to Power: The Unusual Origins of America's World Role, Princeton, Princeton University Press, 1999.

6 Thomas J. Christensen, Useful Adversaries: Grand Strategy, Domestic Mobilization, and Sino-American Conflict, 19471958, Princeton, Princeton University Press, 1996.

7 William Wohlforth, The Elusive Balance: Power and Perceptions During the Cold War, Ithaca, Cornell University Press, 1993.

8 Zakaria, From Wealth to Power, s.42. 


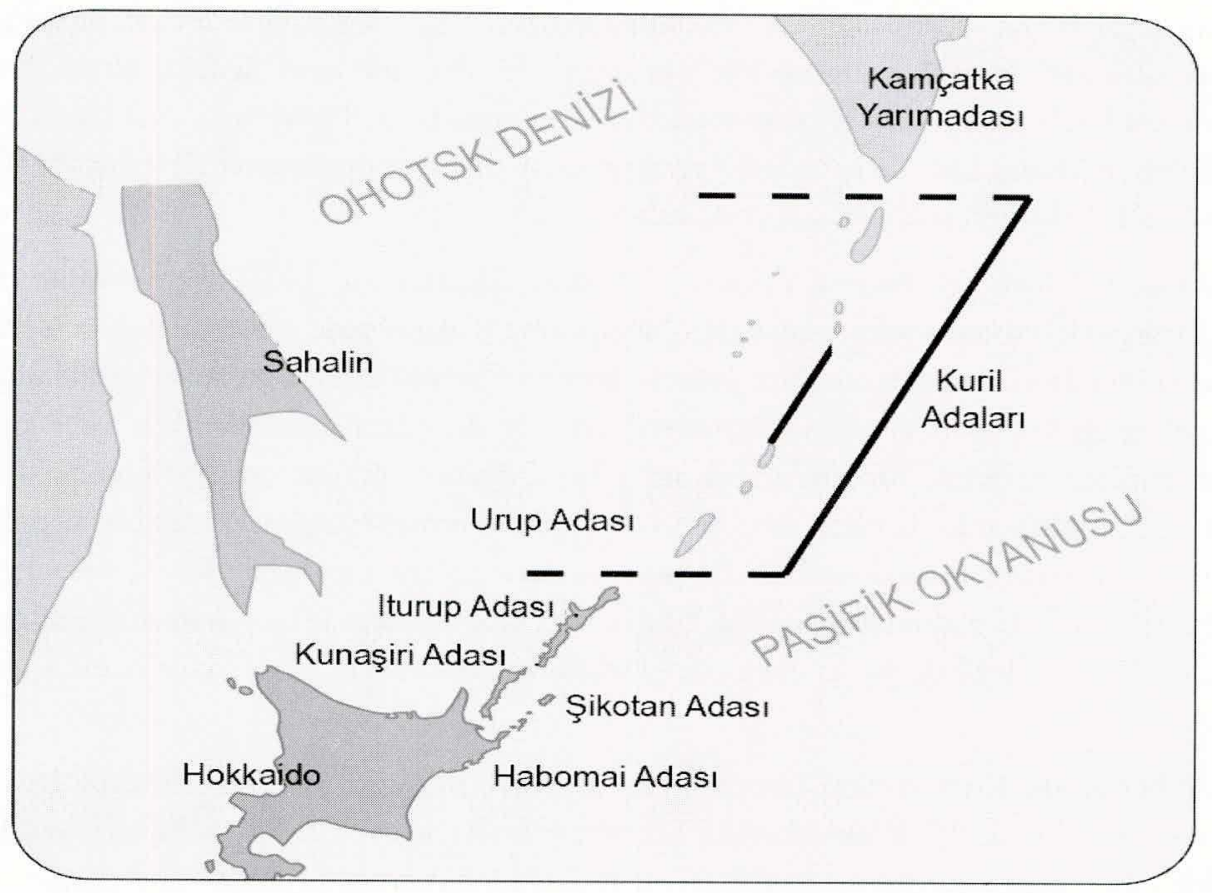

Kaynak: Ministery of Foreign Affairs of Japan, “Japan's Northern Territories: For a relationship of genuine trust”, http://www.mofa.go.jp/region/europe/russia/territory/pamphlet.pdf (Erişim Tarihi 20 Ocak 2015).

Mayıs 1875'te St. Petersburg'da imzalanan Sahalin-Kuril Değişim Antlaşması ile Japonya kontrolü altındaki Sahalin toprağını Rusya’ya devretmiş, bunun karşılığında da Kuril Takımadaları́nın kuzeyindeki tüm adalar üzerinde söz sahibi olmuştur.

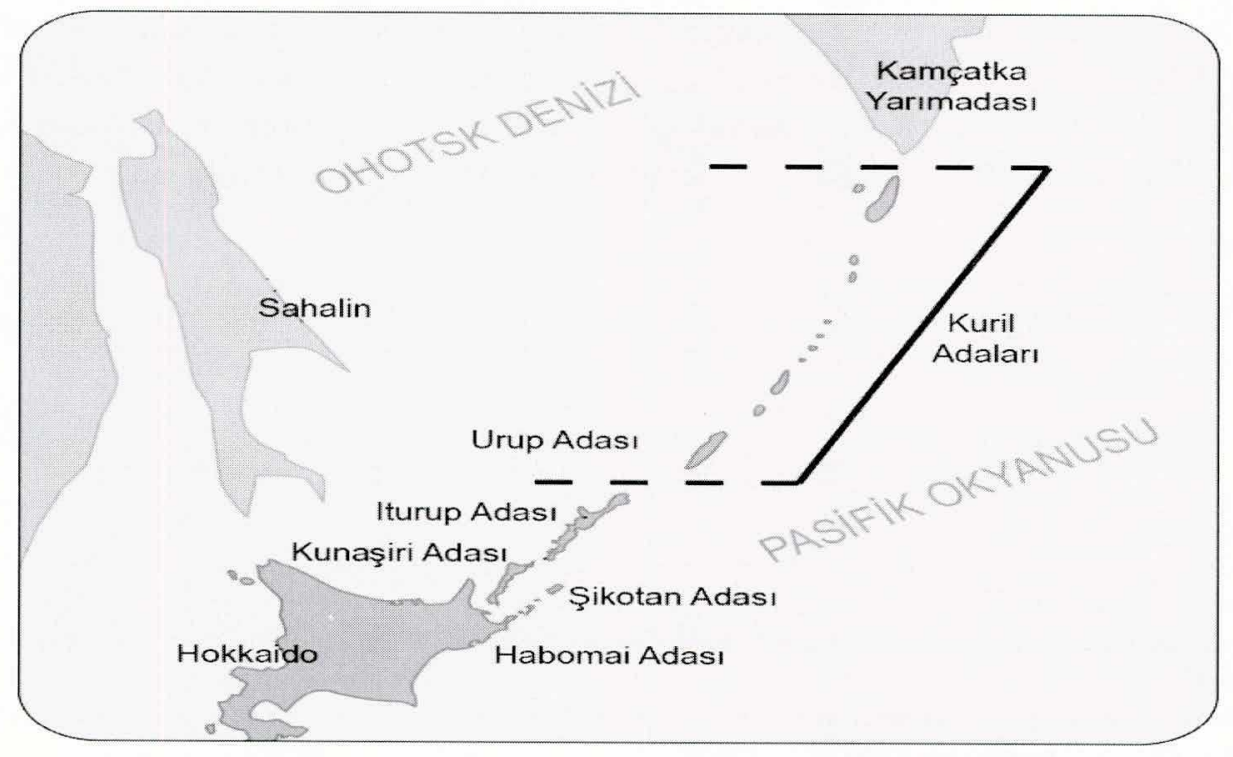

Kaynak: Ministery of Foreign Affairs of Japan, “Japan's Northern Territories: For a relationship of genuine trust", http://www.mofa.go.jp/region/europe/russia/territory/pamphlet.pdf (Erişim Tarihi 20 Ocak 2015) 
Bu mutabakat Japonya’nın kazandığı 1904-1905 Japonya-Rusya Savaşı'na kadar devam etmiştir. Savaşın sonunda ABD'nin Portsmouth Deniz Kuvvetleri Üssü’nde imzalanan Portsmouth Antlaşması sonucunda Rusya, Sahalin Adası'nın güney yarısını Japonya'ya devretmiştir. ${ }^{9}$ Bu durum önemli bir kazanım olmasına karşın tüm Sahalin Adası’nın Japonya'ya dâhil edilmesi gerektiğini savunan Japonlar arasında protestolara yol açmıștır. ${ }^{10}$

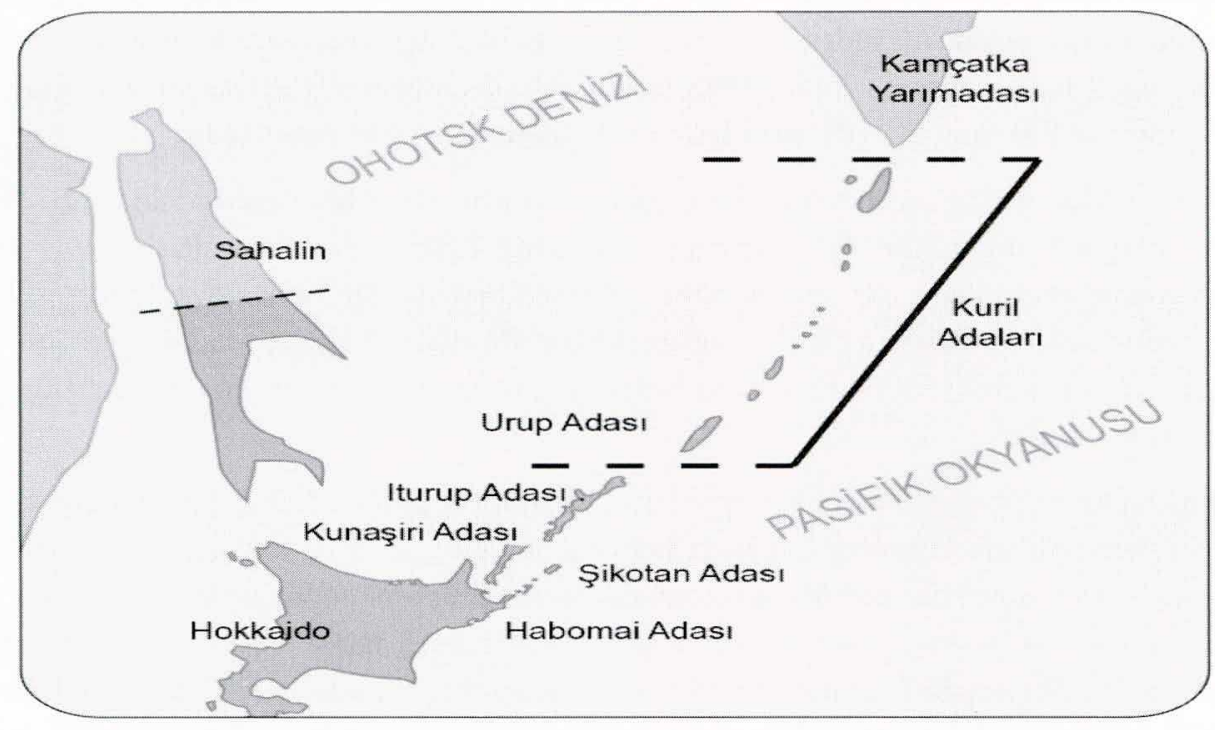

Kaynak: Ministery of Foreign Affairs of Japan, “Japan's Northern Territories: For a relationship of genuine trust", http://www.mofa.go.jp/region/europe/russia/territory/pamphlet.pdf (Erişim Tarihi 20 Ocak 2015)

İkinci Dünya Savaşı́nın bitiminde galip tarafta yer alan Sovyetler Birliği için kaybettiği toprakları ele geçirme şansı doğmuştur. 1943’teki Tahran Konferansı'nda SSCB Devlet Başkanı Stalin, Japonya'nın hem Sahalin hem Kuril Adaları'nı Sovyetler Birliği'ne bırakması gerektiğini dile getirmiştir. ${ }^{11}$ Bu talebin ABD tarafından kabul görmesinin ardından Sovyetler adaları işgal etmiş ve Eylül 1945 'te tek taraflı olarak dört adanın Sovyet toprağı olduğunu açılklamıştır. 1949 yılına kadar adalarda yaşayan Japon halk Japonya’ ya gönderilmiştir.

Sovyetler, 8 Eylül 1951'de müttefik kuvvetler ve Japonya arasında düzenlenen San Francisco Barış Antlaşması Konferansı'na katıldığı halde $A B D$ ve İngiltere'nin sunduğu taslağa karşı çıkarak imza atmamıştır. Sovyetler Birliği Dışişleri Bakan Yardımcısı Andrey Gromiko konferansta önerilen barış antlaşmasını bir Amerikan-İngiliz projesi olarak yorumlayarak ${ }^{12}$, Japonya'nın Sahalin Adası'nın güneyinde bulunan topraklardan ve Kuril ada grubunda bulunan 4 ada üzerindeki hak iddialarından vazgeçmesi gerektiği şeklinde önerilerde bulunmuştur. Bu önerilerin kabul görmemesi üzerine

9 The Treaty of Portsmouth,1905, https://history.state.gov/milestones/1899-1913/portsmouth-treaty (Erişim Tarihi 9 Ocak 2015).

10 Thomas Schoenbaum, Peace in Northeast Asia: Resolving Japan's Territorial and Maritime Disputes with China, Korea and the Russian Federation, Cheltenham, Edward Elgar Publishing, 2008, s.120.

11 Ibid., s.56.

12 Из выступления первого заместителя министра иностранных дел СССР А.А. Громыко на Конференции в Сан-Франциско (Sovyeler Birliği Dışişleri Bakan Yardımcısı Gromiko'nun San Francisco Konferansı'ndaki Konuşmas1), 1951, http://www.hrono.ru/dokum/195_dok/19510905gromy.php (Erişim Tarihi 15 Ocak 2015). 
Sovyetler Birliği barış antlaşmasını imzalamamıştır. Söz konusu antlaşmanın 2 ve 3. maddelerine göre Japonya; 1905 yılında ele geçirdiği Kore, Tayvan, Peng-hu, Kuril Adaları (Chishima), Sahalin Adaları'nın güney bölgeleri, Güney Çin Denizi'ndeki Spratly ve Paracell Adaları üzerindeki haklarını devrettiğini kabul etmektedir. ${ }^{13}$ Ancak bahsedilen antlaşmada Güney Kuril Adalarıla ilgili net bir ifade bulunmamaktadır.

Moskova ihtilaflı dört adanın dâhil olduğu Güney Kuril ada grubunun İkinci Dünya Savaşı́ndaki galibiyetinin sonucu olarak Sovyetler Birliği’ne katıldığı görüşünü savunmaktadır. Rusya, Güney Kuril Adaları́nın yasal statüsünün; 11 Şubat 1945 tarihli Yalta Konferansi ${ }^{14}$, 26 Temmuz 1945 Potsdam Deklarasyonu ${ }^{15}$ ve BM Şartı́nın 107. maddesi ${ }^{16}$ ile belirlendiğini iddia etmektedir.

Kuril Adaları Rusya açışından stratejik öneme sahiptir. Zira adalar üzerindeki kontrol Ohotsk Denizi’ne çıkış için önemlidir. Aynı zamanda Rusya'nın Pasifik Filosu'nun Pasifik Okyanusu'na çıkışı açısından ehemmiyet arz etmektedir. Güney Kuril Adaları arasındaki derin sular Rus denizaltılarının açık okyanuslara çıkışını sağlamaktadır. Bu adaların kaybedilmesi Rusya'nın Pasifik Filosu'nun harekât kabiliyeti ve Rusya'nın bölgesel güvenliği açısından ciddi dezavantaj olarak değerlendirilmektedir. ${ }^{17}$

İkinci Dünya Savaşı sırasında Sovyetler'in sınırlarına dâhil edilmiş birçok toprak parçası uluslararası antlaşmalarla tanınmış olmasına rağmen, Japonya ile barış antlaşması imzalanmaması dört ihtilaflı adanın Sovyetler Birliği toprağı olarak tanınmamasına neden olmuştur. Ancak 1944'te Pasifik Okyanusu'nda Japonya'ya ait Marian, Karolin, Marshal Adaları ve Palau Takımadası'nın ABD tarafindan işgal edilmesi BM tarafindan 1947'de tanınmıştır. Burada belirtilmesi gereken husus, ABD'nin ideolojik olarak Sovyetler Birliği'nin karşısında yer almasının söz konusu adaların Sovyet toprağı olarak kabul edilmemesinde etkili olduğudur.

Japonya ise iddialarını öncelikle tarihi öğelere dayandırmaktadır. Kuzey Toprakları, Japonya'nın doğal toprakları (inherent territory) yani eski zamanlardan itibaren sadece bir ulusa ait olması sebebiyle tarihi ve hukuki açıdan ilgili ülkenin sayılan toprak olarak görülmektedir. ${ }^{18}$ Zira söz konusu dört ada (Sahalin ve Kuzey Kuril Adaları'ndan farklı olarak) 1945 yılına kadar Japonya'ya ait olup 18. yüzyıldan beri Japonya'yı oluşturan dört büyük adadan biri olan Hokkaido'nun bir parçası olarak yönetilmiştir.

Japonya taraf olmadığı Yalta Konferansı’nın bu konuda bağlayıcı olamayacağını, zira uluslararası hukuka göre Japonya'nın rızası olmadan galip devletlerin Japon topraklarını paylaştıramayacağını savunmaktadır. Ayrıca Japonya 1949 tarihli Dördüncü Cenevre Sözleşmesi’nin savaş sonrası işgalci güçlerin işgal ettikleri toprakların bir kısmını veya tamamını ilhak edemeyeceğini öngören 47.

13 Treaty of Peace with Japan, San Francisco, September 8, 1951, https://treaties.un.org/doc/Publication/UNTS/ Volume\%20136/volume-136-I-1832-English.pdf (Erişim Tarihi 15 Ocak 2015).

14 Yalta Konferansı'nda Franklin D. Roosevelt ve Winston Churchill Japonya'ya karşı savaşa girmesi karşıllı̆ında Joseph Stalin’e Sahalin Adaları'nın güneyini ve Kuril Adaları'nı verme taahhüdünde bulunmuştur.

15 Potsdam Deklarasyonu; Japonya’nın Honsyü, Hokkaydo, Kyüsyü ve Sikoku Adaları ve galip devletlerin belirlediği diğer adalar üzerindeki egemenlik hakkını tanımaktadır. Deklarasyona istinaden, 29 Ocak 1946 tarihinde Japonya'daki ABD Askeri İdaresi tarafından Tokyo hükümetine gönderilen 677 sayılı yönergede Şikotan ve Habornai de dâhil olmak üzere tüm Kuril Adaları üzerinde Japonya'nın egemenlik hakkının tanınmadığı belirtilmiştir.

16 BM Şartı Madde 107: İşbu Antlaşmanın hiçbir hükmü, Antlaşmayı imzalayan herhangi bir devletin İkinci Dünya Savaşı sırasında düşmanı durumunda olan bir devlete karşı, bu konuda sorumluluk sahibi hükümetlerin söz konusu savaşın sonucu olarak giriştiği ya da girişilmesini uygun bulduğu bir eylemi ne etkiler, ne engeller.

17 Dmitry Gorenburg, "The Southern Kuril Island Dispute”, PONARS Eurasia Policy Memo, No.226, September 2012 , s.5.

18 Hiroshi Kimura, Japanese-Russian Relations Under Brezhnev and Andropov, Cilt 1, Armonk, New York, Sharpe, 2000 , s.58. 
maddesini öne sürmektedir. ${ }^{19}$ Japonya teslim olmasından hemen önce Sovyetler'in söz konusu adaları işgal etmesini hukuksuz bir saldırı olarak nitelendirmektedir.

Tokyo hükümeti, San Francisco Barış Antlaşması konusunda bu antlaşmada geçen "Kuril Adaları" ibaresinin Japonya'nın güneyinde bulunan dört adayı kapsamadığını çünkü “Kuril Adaları"nın 1875 'te Rusya tarafindan Japonya’ya bırakıldığını, söz konusu dört adanın ise bu dönemde zaten Japonya' ya ait olduğunu dile getirmektedir. Öte yandan Sovyetler' in bu anlaşmanın tarafı olmadığından anlaşma hükümlerinden zaten faydalanamayacağını savunmaktadır.

Japonya için adaların teşkil ettiği önemin nedenlerine bakılacak olursa ilk olarak bu adaların Hokkaido'ya yaknlıkları sebebiyle stratejik öneme sahip oldukları söylenebilir. Bu adalara sahip olmak Japon anakarasını dış müdahalelerden korumak açısından önem taşımaktadır. Ayrıca Kuzey Toprakları balıkçılık ve zengin madenleri sebebiyle ekonomik açıdan da önemlidir. Ancak adaların stratejik ve ekonomik öneminin kayda değer nitelikte olmadığı ve Japonya'ya ait olması durumunda mevcut konjonktürde değişiklik yaratmayacağını söylemek mümkündür. Dolayısıyla adaların Japonya için daha çok sembolik bir önem arz ettiğini ifade etmek yanlış olmayacaktır. Dört adanın kaybı Japonlar tarafından İkinci Dünya Savaşı hezimetinin son sembolü olarak görülmektedir. Okinawa’nın 1972'de Japonya'ya iadesinden sonra Kuzey Toprakları Japonya’nın sömürgecilik döneminden önce sahip olup da geri alamadığı son topraklar olarak kalmıştır.

Kuzey Toprakları sorunu, Tokyo hükümetinin Japon kamuoyunun dikkatini bu meseleye çekmek için uyguladığı kampanya (eğitim faaliyetleri, anma törenleri, 7 Şubat'ın Kuzey Toprakları günü ilan edilmesi gibi) sonucu Japonya’nın milli meselesi haline dönüşmüştür. Bu kampanyanın ABD’ye karşı gelişmeye başlayan Japon milliyetçiliğinin Sovyetlere karşı geliştirilmek istemesinin bir sonucu olduğu değerlendirmeleri yapılmaktadır. ${ }^{20} \mathrm{Bu}$ sorunun milli mesele haline gelmesi Rusya ile ilişkilerin yeterince geliştirilememesinde önemli etkiye sahiptir.

\section{Sorunun Tarihsel Gelişimi}

İkinci Dünya Savaşı́nın sonunda taraflar arasında imzalanmış bir barış antlaşmasının bulunmamasının da etkisiyle uzun bir süre diplomatik iliski goliştirememiştir. 1955 yılında Sovyetler'in Tokyo'da bulunan temsilcisi, Japonya Dışişleri Bakanı Mamoru Şigemitsu’ya iki ülke arasındaki ilişkilerin normalleştirilmesine yönelik görüşme talebinde bulunmuştur. Bunun üzerine Haziran 1955'te Londra'daki Sovyet Büyükelçiliği binasında gerçekleşen Sovyet-Japonya görüşmelerinde Japon tarafı barış antlaşması imzalanması için kendi önerisini açıklamıştır: Habornai, Şikotan ve Sahalin Adasının güney kısmının iadesi. Japonya Sovyetler'in bu talepleri kabul etmeyeceğini bilmekle birlikte diplomasiyle adım adım çözüme yaklaşma stratejisi izlemekteydi. Japonya için en önemli amaç, yüzölçümü olarak diğerlerinden küçük olmakla birlikte Pasifik'teki münhasır ekonomik bölgesi daha geniş ve deniz kaynakları bakımından daha zengin Habornai ve Şikotan adalarının alınması idi. Bunun için önce Güney Kuril Adaları’nın tümünün talep edilmesi, en sonunda da iki adanın Japonya'ya iadesinde anlaşılması hedeflenmekteydi. Dönemin Japonya Başbakanı İçiro Hatoyama Ocak 1955’te

19 The Geneva Conventions of 12 August 1949, https://www.icrc.org/eng/assets/files/publications/icrc-002-0173.pdf (Erişim Tarihi 20 Ocak 2015).

20 Alexander Bukh, “Takeshima' and 'Northern Territories' in Japan's Nationalism”, China Policy Institute, October 16, 2014, http://blogs.nottingham.ac.uk/chinapolicyinstitute/2014/10/16/takeshima-and-northern-territories-in-japansnationalism/ (Erişim Tarihi 20 Ocak 2015). 
Sovyet temsilcileriyle yaptığı görüşmede diplomatik ilişkilerin kurulması için iki adanın Japonya ya verilmesi gerektiğini açıkça belirtilmişti. ${ }^{21}$

Hatoyama’nın bu stratejisi Soğuk Savaş ortamındaki göreceli değişimden bağımsız değildir. Uluslararası sistemde mevcut bloklar arası gerginliğin üst seviyede olduğu bu dönemde, 1953 yılında Stalin'in ölümü ve Kore Savaşı'nın bitimiyle bölgede göreceli bir barış ortamının sağlanmış olması Japonya-Rusya yakınlaşmasını mümkün kılmıştır. Hatoyama Japonya için mümkün olan en kazançlı anlaşmayı yapma çabası içerisindedir. Zira uluslararası sistemi şekillendiren iki büyük güçten biri ile savaşı göze alamayacağından diplomasi yoluyla çözüme gitmeyi tercih etmek durumundadır. Ancak bu sistemsel etmenlerin yanında iç faktörler de göz ardı edilmemelidir. Bu kapsamda devlet-toplum ilişkisine bakıldığında Hatoyama'nın militarist ve milliyetçi çizgideki politik söylemleriyle, 2. Dünya Savaşı sonrası yenilmiş ve aşağılanmış hisseden Japon halkına hitap etmeye çalıştığı görülmektedir. Nitekim başbakanlığı süresince öncelikli hedef olarak, bağımsız dış politika izlenmesini ve anayasanın gözden geçirilmesini belirlemiştir. ${ }^{22}$ Bağımsız dış politika hedefi doğrultusunda Sovyetler ile ilişkiler yeniden ele alınmaya çalışılmıştır. Ancak Hatoyama yönetiminin hesaplayamadığı sistemsel ve iç etmenler, bu girişimin başarısızlıkla sonuçlanmasına neden olmuştur. Öncelikle Sovyetler ile Kuril Adaları́nın tamamını kapsamayan bir anlaşma imzalama çabası milliyetçi kesimin tepkisine ve protestolarına sebebiyet vermiştir. Öte yandan Hatoyama parlamentoda çoğunluğu elde edebilmek adına liderliğini yaptığı Japon Demokratik Partisi ile Şigeru Yoşida'nın liderliğindeki Liberal Parti’nin Liberal Demokratik Parti adı altında birleşmesine ön ayak olmuştur. Fakat bu durum dış politika konuları başta olmak üzere parti içi muhalefeti beraberinde getirmiştir. Sovyetler ile söz konusu minvalde bir anlaşma imzalanmasına olumsuz yaklaşanların başında Dışişleri Bakanı Mamoru Şigemitsu ve bakanlık bürokratları bulunmaktaydı. ${ }^{23} \mathrm{Bu}$ bürokratlar diplomat olarak görev yapmış Yoşida'nın yanında yer almıştır. Ayrıca Japon-ABD Güvenlik Antlaşması'na karşı olmamakla birlikte Japonya'nın dış politika bağlamında tam bağımsızlığını tesis etme arzusu Hatoyama'nın Gaullist olarak algılanmasını ${ }^{24}$ ve ABD’nin Japonya üzerindeki baskısını beraberinde getirmiştir.

Diplomatik ilişkilerin tesisi amacıyla Moskova ve Tokyo'nun 1955'te gerçekleştirdiği görüşmeler ABD'yi rahatsız etmiştir. Bu sebeple ABD yönetimi Japon dışişleri bakanının Mart 1955'te Washington'ı ziyaret isteğini reddetmiştir. Ekim 1955'de ABD Dışişleri Bakanı John Foster Dulles tarafından Japonya'ya gönderilen diplomatik notada Tokyo'nun Kuzey Toprakları'ndan vazgeçmesi durumunda $A B D$ 'nin kontrolündeki Okinawa adasını geri alamayacağı ve $A B D$ tarafından Japonya'ya yapılan yardım programlarının durdurulacağı belirtilmiştir. ${ }^{25}$ Öte yandan 7 Eylül 1956'da ABD Dışişleri Bakanlığı tarafından yayınlanan bildiride, Japonya ile Sovyetler Birliği arasında imzalanacak ve San Francisco Antlaşması’nın hükümlerinde değişiklik yaratacak herhangi bir barış antlaşmasının kabul edilmeyeceği beyan edilmiştir. ${ }^{26}$

21 Кошкин, Анатолий / Koshkin, Anatoliy, “Правая история: Почему нет мирного договора с Японией” (Gerçek Tarih: Neden Japonya ile barış antlaşması yok?), 20 Ekim 2014 (Erişim Tarihi 10 Ocak 2015).

22 Frank N. Magill (der.), Dictionary of World Bibliography, Cilt 8, NewYork, Routledge, 1999, s.1577.

23 Joseph Ferguson, Japanese-Russian Relations, 1907-2007, NewYork, Routledge, 2008, s.34.

24 Mayumi Itoh, The Hatoyama Dynasty, NewYork, Palgrave, 2003, s.131.

25 Clark, Gregory, "Northern territory dispute highlights flawed diplomacy", www.japantimes.co.jp/opinion/2005/03/24/ commentary/northern-territories-dispute-highlights-flawed-diplomacy/\#.VOGpclxjDwI (Erişim Tarihi 16 Ocak 2015).

26 102. Memorandum of a Conversation, Secretary Dulles' Residence, Foreign Relations of the United States, 1955-1957, Volume XXIII, Part 1, Japan, Document 102, Washington, Eylül 7, 1956, http://history.state.gov/historicaldocuments/ frus1955-57v23p1/d102 (Erişim Tarihi 19 Ocak 2015). 
SSCB açısından bakıldığında; 1955 Cenevre Konferansı́nın Sovyetler ile ABD arasındaki gerilimi düşürmesi, Kuzeydoğu Asya ve Orta Avrupa'da patlak verebilecek bir nükleer savaş endişesi, 1953’ten sonra başlatılan Stalin kültünün yok edilmesi politikası sonucu Çin ile gerilen ilişkiler bu dönemde Kruşçev'i Japonya ile yakınlaşmaya teşvik etmiştir. Öte yandan Kuril adalarından ikisinin Japonya'ya iadesi, ABD'nin kontrolündeki Okinawa adası için aynı beklentiyi yaratarak ABD-Japonya ittifakını Sovyetler lehine bozabilecekti. Bu sistemsel faktörlerin yanında değerlendirmeye alınması gereken unsur, Kruşçev'in Stalin kültünün yok edilmesi politikasıdır. Kişinin putlaştırılması olarak nitelendirdiği Stalin dönemi uygulamalarına karşı çıkan Kruşçev, bu dönemdeki dış politikanın SSCB'yi dış dünyadan soyutladığı gerekçesiyle eleştirmiş ve yeni açılımlar gerçekleştirilmesi gerektiğini belirtmiştir. Bu çerçevede Sovyetler ve sosyalist ülkeler ile kapitalist ülkelerin bir arada barışçıl şekilde varlığını sürdürmesine dayanan "barış içinde bir arada yaşama” teorisini öne sürmüştür.

Taraflar arasında bir barış antlaşması imzalanamamasına rağmen Japonya ve Sovyetler Birliği arasındaki diplomatik ilişkiler 1956'da tesis edilmiş ve Ekim 1956'da Japonya-Sovyet Ortak Deklarasyonu imzalanmıştır. ${ }^{27}$ Söz konusu deklarasyonda savaşın sona ermesi ve diplomatik ilişkilerin kurulması, Japonya'nın BM üyeliğinin desteklenmesi ve Sovyetler'in savaş tazminatından vazgeçmesi gibi konular yer almaktadır. Adalarla ilgili olan 9. maddede Japonya'nın ilgili dört adadan ikisi olan Etorofu ve Kunashiri adalarındaki hak taleplerinden vazgeçmesi doğrultusunda, Sovyetler'in Şikotan ve Habornai adalarını Japonya'ya devredebileceği ifade edilmektedir. ${ }^{28}$ Rusya'nın bu iki adadan feragat etmesi, Habornai'de küçük bir askeri birlik dışında kimsenin yaşamıyor oluşu ve Şikotan halkının büyük kısmının Japonya'ya bağlanmayı istemesiyle açıklanabilir. ${ }^{29}$ Fakat adalarının iadesinin taraflar arasında imzalanacak barış antlaşması sonucunda gerçekleşeceği vurgulanmıştır. Ancak bu deklarasyon, ABD'nin Sovyetleri çevreleme politikasına uygun olmadığı için sıcak bakmaması ve Japonya'da Başbakan İşibaşi'nin istifası sonrasında göreve Amerika yanlısı çizgideki Nobusuke Kişi’nin gelmesi sonucunda yürürlüğe girmemiştir.

2. Dünya Savaşı sırasında hükümette yer alan Kişi, savaş sonrası kurulan Uzakdoğu Askeri Ceza Mahkemesi tarafından A Sınıf Savaş Suçlusu olarak hüküm giymiştir. Ancak ABD'nin Kişi'yi Soğuk Savaş konjonktüründe Japonya'yı Washington' ın politikalarıyla uyumlu bir çizgide yönetebilecek bir lider olarak görmesi sonucu serbest bırakılmıştır. Kişi’nin 1957'de göreve gelmesinde olduğu gibi Kuril adaları meselesine bakışında da uluslararası sistem belirleyici konumdadır. Bununla birlikte muhafazakârmilliyetçi çizgideki Kişi, Japonya’nın yeniden savaş ilan etme hakkına kavuşması için anayasanın bağlayıcı maddelerinin değiştirilmesini, bunun için de $\mathrm{ABD}$ ile güvenlik ilişkilerinin geliştirilmesi gerektiğini düşünmekteydi. Bu sebeple ABD ile imzalanmış Güvenlik İşbirliği Anlaşması́nın 1960 yılında yenilenmesi konusunda ülke çapında protestolara rağmen ısrarcı davranmıştır.

19 Ocak 1960'da ABD-Japonya arasında askeri-savunma alanında imzalanan geniş kapsamlı antlaşmayla Japonya kendi topraklarındaki Amerikan askeri üslerinin varlığını 10 yıl daha uzatmıştır. Bu antlaşmanın imzalanması sonrası Kruşçev, 27 Ocak 1960'da Sovyetler'in Japonya'ya vaat ettiği iki adanın iadesinden vazgeçildiğini duyurmuştur. Bu kararı imzalanan askeri antlaşmanın kendisine yönelik oluşturduğu tehdit ve adaların iadesi durumunda bu bölgelerde de ABD askeri üslerinin kurulması tehlikesi ile açıklamıştır. ${ }^{30}$

27 Joint Declaration by the Union of Soviet Socialist Republics and Japan, October 19, 1956, http://www.ioc.u-tokyo. ac.jp/ worldjpn/documents/texts/docs/19561019.D1E.html (Erişim Tarihi 20 Ocak 2015).

28 Ibid.

29 Brad Williams, Resolving the Russo-Japanese Territorial Dispute: Hokkaido-Sahalin Relations, NewYork, Routledge, 2007 , s.133.

30 Памятная записка Правительства СССР Правительству Японии от 27 января 1960 года (SSCB'nin Japonya'ya 27 Ocak 1960 tarihli diplomatik muhtırası), http://www.ru.emb-japan.go.jp/RELATIONSHIP/MAINDOCS/ normal.html\#4 (Erişim Tarihi 10 Ocak 2015). 
SSCB'nin dağılmasıyla uluslararası sistemde gerçekleşen radikal değişim Rusya-Japonya ilişkilerini de etkilemiştir. İki ülkenin yakunlaşmasının önündeki ABD engeli Soğuk Savaş'ın bitimiyle eski ağırlığını yitirmiştir. Ayrıca bölgede gücünü artırmaya başlayan Çin hem Moskova hem de Tokyo'nun dış politikalarını belirlerken göz önünde bulundurmaları gereken bir unsur haline gelmiştir. İç dinamiklere bakıldığında Japon liderlerin Japonya'nın 80'li yıllardan beri artan ekonomik gücünün kazandırdığı özgüvenle hareket ettikleri ve Rusya ile ilişkilerde de bu özgüvenin hissedildiği söylenebilir. Bu bağlamda Japon Dışişleri Bakanlığı içinde iki grup ortaya çıkmıştır: Kuril adaları sorunu çözülünceye kadar Rusya'ya ekonomik yardımda bulunmayı reddedenler ile Rusya ile ekonomik yardımlar da dâhil ilişkilerin geliştirilmesi gerektiğini savunanlar. ${ }^{31}$ Bakanlık içindeki bu bölünme iktidardaki Liberal Demokrat Parti’nin dış ilişkilerde etkili olmasına olanak sağlamakla birlikte siyasi skandallar, Sovyetler ile ilişkilerde ivme kaydedilemeden, 1993 yılında bu partinin iktidarı kaybetmesine neden olmuştur. Toplum açısından bakıldığında Japon halkında ekonomik güce dayalı bir milliyetçilik yükselirken bölgesinde yeniden söz sahibi bir Japonya algısı oluşmaya başlamıştır. Medyada Sovyetlerin dağılmasının Kuril adalarının hâkimiyetini ele geçirmek için uygun bir fırsat olduğu haberleri yer almaya başlamış ve halkın adaların tümünün Japonya'ya katılması beklentisi daha da artmıştır. ${ }^{32}$

1990’lı yılların başlarında Boris Yeltsin hükümeti içindeki Atlantikçi olarak bilinen siyasi elitlerin Güney Kuril Adaları'nın Japonya'ya verilmesine sıcak yaklaşmasına rağmen yüksel(til)en milliyetçilik sebebiyle genel politikadan herhangi bir taviz verilmesi söz konusu olmamıştır. Zira bu dönem Ruslar için yeni millî kimlik ve millî devlet inşasının başlangıcı olup dış politika söylem ve uygulamaları bu inşayı destekleyecek mahiyettedir. Bununla birlikte Japonya ile Rusya arasında Nisan 1991'de ilan edilen ortak bildiride her iki tarafin tutumuna bağlı olarak söz konusu dört ada üzerinde müzakere yapılabileceği beyan edilmiştir. ${ }^{33}$ Sovyetler'in başlangıçta bir toprak ihtilafinın mevcut olduğunu reddettiği göz önünde bulundurulursa bu gelişme, Japonya açısından diplomatik bir başarı olarak değerlendirilebilir.

Ayrıca ilişkileri güçlendirmek adına Japonya, Sovyetler Birliği'nin dağılmasının yarattığı sorunlarla uğraşan Rusya'ya yardım amaçlı olarak ihtilaflı dört adada yaşayan halka insanı yardımda bulunmuştur. 1991'den itibaren bu adalarda yaşayan halka Japonya'ya vizesiz girme imkânı tanınmış, aynı imkân Rusya tarafindan eskiden adalarda ikamet eden Japonlara da sunulmuştur. Ekim 1993'teki Tokyo Ortak Bildirisi’nde, ilgili dört adanın egemenliği konusunda tarihi gerçekler ve hukuki temeller üzerinde ciddi müzakereler yapılabileceği, Kasım 1998'deki Moskova Ortak Bildirisi’nde ise toprak ihtilafının çözümü için bir çalışma grubunun oluşturulacağı ifade edilmiştir. ${ }^{34}$

Sorunun çözümüne yönelik en önemli gelişme ise 2005 yılında Rusya'nın ihtilaflı dört adadan ikisini Japonya'ya vermesi, buna karşılık Tokyo hükümetinin diğer iki ada üzerindeki hak iddiasından vazgeçmeyi kabul etmesi önerisiyle yaşanmıştır. 2000 yılında devlet başkanlığı görevini üstlenen Vladimir Putin, Habornai ve Şikotan adalarının Japonya'ya iadesinin mümkün olabileceğini dile getirmiştir. ${ }^{35}$

31 Ferguson, Japanese-Russian Relations, s.70.

32 Ibid., s.76

33 Hiroshi Kimura, The Kurillian Knot: A History of Japanese-Russian Border Relations, California, Stanford University Press, 2008, s.168.

34 Tokyo Declaration on Japan-Russia Relations, October 13, 1993, http://www.mofa.go.jp/region/n-america/us/ q\&a/declaration.html; Moscow Declaration on Establishing a Creative Partnership between Japan and the Russian Federation, November 13, 1998, http://www.mofa.go.jp/region/europe/russia/territory/edition01/moscow.html (Erişim Tarihi 22 Ocak 2015).

35 Menas Borders, "Claim and counter-claim in the Kuril islands dispute", MENAS, April 2011, http://www.menas.co.uk/ documents/menas-kurils.pdf (Erişim Tarihi 22 Ocak 2015). 
Fakat bu öneride iki adanın iade edilmesinden önce Japonya’nın bu adaların Rusya’ya ait olduğunu kabul etmesi gerektiği vurgulanmıştır. Bu sebeple dönemin Tokyo hükümeti bu öneriyi kabul etmemiştir.

Dimitri Medvedev'in cumhurbaşkanlığı dönemi ise karşılıklı provokatif eylemlere sahne olmuştur. Japonya adalar üzerindeki hak taleplerini yasallaştırmak için Temmuz 2009'da Japon Meclisi'nin kabul ettiği Kuzey Toprakları Meselesinin Çözümü ile İlgili Özel Tedbirler Yasasının (Güney Kuril Adaları́nın Japonya’nın toprağı olduğunu ve Rusya tarafından hukuka aykırı şekilde işgal edildiği vurgulamaktaydı) kabulü, dönemin Ulaştırma Bakanının Kunaşiri Adası’nı ziyareti gibi girişimlerde bulunmuştur. Buna karşılık Medvedev'in "Rusya'nın askeri zaferleri ve önemli tarihleri” isimli yasadaki değişikliklere ilişkin imzaladığı önerge ile 2 Eylül 1945 tarihi İkinci Dünya Savaşı’nın bitiş tarihi olarak belirlenmiştir. ${ }^{36} \mathrm{Bu}$ tarih aynı zamanda Japonya üzerinde Sovyetler Birliği'nin zafer günü ${ }^{37}$ ve Japonya'nın savaş mağlubu olarak teslimiyet belgesine imza attığı gün olarak gösterilmektedir ki bu yasa değişikliği Tokyo hükümetinin tepkisini çekmekte gecikmemiştir. Ayrıca Kasım 2010'da Medvedev Kunaşiri Adası'na gelerek adayı ziyaret eden ilk Rus cumhurbaşkanı olmuş, Temmuz 2012'deki başbakanlık görevi sırasında da adayı ikinci defa ziyaret etmiştir.

Medvedev'in ilk ziyareti sonrasında Japonya, Rusya’nın Tokyo Büyükelçisi Mihail Beli'yi Dışişleri Bakanlığı'na çağırarak tepki göstermiş; ardından Japonya’nın Moskova Büyükelçisi Masaharu Kono'yu Tokyo'ya geri çağırarak diplomatik krize yol açmıştır. Beş gün süren kriz sonrasında büyükelçinin Moskova'ya dönmesi, Japonya muhalif partilerinin hükümeti Rusya karşısında zayıf davranmakla suçlamasına sebep olmuştur. Kono'nun Moskova’ya tekrar geri dönme nedeninin Kasım 2010'da Yokohama kentinde yapılacak ve Rusya'nın da katılacağı Asya-Pasifik Ekonomik İşbirliği (APEC) Liderler Zirvesi ile ilgili olduğunu bildiren hükümet, ülkenin Rusya ile olan adalar sorununu çözmek için yeni bir strateji oluşturulduğunu ifade etmiştir. ${ }^{38}$ Tokyo'nun Moskova'daki büyükelçisini çekmesi ve kısa sürede geri göndermesiyle ilgili tepki çeken tutumu, Çin'in Asya-Pasifik bölgesinde artan nüfuzunun ve Okinawa'daki $\mathrm{ABD}$ askeri üssünün kaldırılması talebi sebebiyle $\mathrm{ABD}$ ile yaşanan gerginliğin yol açtı̆̆ı belirsizlik ve endişeden bağımsız değerlendirilmemelidir. Bununla birlikte Başbakan Hatoyama'nın Okinawa üssünün kaldırılacağı sözünü tutamaması ve adının karıştığı siyasi finansman skandalı sebebiyle Haziran 2010'da istifa etmesi üzerine göreve gelen Naoto Kan'ın bir yandan ABD ile ilişkileri yeniden düzeltme bir yandan da ekonomideki kötü gidişi durma çabası gibi iç değişkenler de göz önünde bulundurulmalıdır. Zira Okinawa üssünün kaldırılmaması sebebiyle hassas olan halkın tepkisi, Medvedev'in Kuril adaları ziyaretine sessiz kalınarak çekilmek istenmemiştir. Öte yandan dış politika anlamında belirsizliklerin hâkim olduğu bir ortamda Rusya ile ilişkilerin daha fazla gerilmemesi arzu edilmediğinden ki bu durum ekonomik gidişatın kötü olduğu Japonya'da iş çevreleri tarafından da istenmeyen bir durumdur, büyükelçi geri gönderilmiştir.

Rusya’nın son yıllarda bölgede savunma gücünü artırmak amaçlı izlediği politikalar, Şubat 2011'de Kuril Adaları'na güdüm füze sistemi yerleştirebileceği ile ilgili kararı ${ }^{39}$ Iturup ve Kunaşir'de iki yeni askeri birlik oluşturulması planı ${ }^{40}$ gibi provokatif nitelikteki adımlar ilişkilerin geliştirilmesini

36 Bu yasa Rusya Devlet Duması'nda 7 Temmuz 2010'de kabul edilmiş ve 14 Temmuz 2010'da Rusya Federal Meclisi'nde onaylanmıştır.

37 Sovyetler Birliği döneminde 3 Eylül 1945 Japonya'ya karşı zafer günü olarak kutlanmaktaydı.

38 “Japanese Ambassador returns to Moscow", Kyodo News, 8 Kasım 2010, http://www.japantimes.co.jp/news/2010/11/08/ national/japanese-ambassador-returns-to-moscow/\#.VOG8C1xjDwI (Erişim Tarihi 12 Ocak 2015).

39 "Russia to deploy modern missile defense systems on disputed Kuril Islands", RIA Novosti, February 15, 2011, http:// www.eurasiareview.com/15022011-russia-to-deploy-modern-missile-defense-systems-on-disputed-kuril-islands/ (Erişim Tarihi 12 Ocak 2015).

40 Viktora Litovkin, “Курильская военная аномалия”, Nezavisimaya Gazeta, 13 Ekim 2011, http://nvo.ng.ru/ nvo/2011-10-13/1_kurily.html (Erişim Tarihi 24 Ocak 2015). 
ve adalar sorununun çözümüne yönelik ciddi girişimleri önemli ölçüde engellemiştir. Fakat gerek mevcut sorunun çözümünün gerekse ekonomik çıarların Rusya ile iyi ilişkileri gerektirdiğini düşünen Başbakan Şinzo Abe'nin Rus Devlet Başkanı Putin ile geliştirdiği diyalog ilişkilere uzun yıllardır yakalanamayan bir ivme kazandırmıştır.

\section{Ukrayna Krizi'nin İkili ilişskilere Etkisi}

Başbakan Şinzo Abe Aralık 2012'de iktidara geldiğinde proaktif bir dış politika izlemeye gayret etmiş, Rusya ile durağan ilişkileri canlandırmak için ciddi adımlar atmıştır. Bu adımlardan en önemlisi diğer G-8 ülkelerinin Ukrayna krizi sebebiyle boykot etmesine rağmen Putin'in daveti üzerine Abe'nin Şubat 2014'te Soçi Kış Olimpiyatları’nın açılış törenine katılmasıdır. Bu tören 2012 yılı sonundan itibaren iki lideri 5. kez bir araya getirmiştir. Yapılan tüm bu görüşme ve zirvelerin sonucunda ekonomik ilişkilerin güçlendirilmesi ve Kuril Adaları sorununun çözümüne yönelik adımların atılması, böylece ikili ilişkilerin normalleştirilmesi kararları alınmıştır.

Rusya ile ilişkilerin geliştirilmesi Japonya için hem enerji güvenliği hem de bölgede artan Çin etkisini dengelemek adına önem taşımaktadır. 2011'de Fukuşima'da yaşanan nülkleer reaktör kazasının ardından nükleer reaktörlerin kullanımını sınırlandıran Japonya, karşı karşıya kaldığı enerji açığı sorununu aşmak için Rusya'dan gelecek doğalgaza ihtiyaç duymaktadır. Öte yandan Rusya’nın hem ekonomik hem de askeri anlamda Asya'daki nüfuzunu artıran Çin ile stratejik ortaklık ilişkisi içerisinde bulunması Tokyo'yu durumu dengelemek adına Moskova ile iyi ilişkiler kurmaya itmektedir. Moskova için de Tokyo ile ilişkileri geliştirmeye yönelik dış politikanın temel yapısal faktörü Çin'in bölgede artan etkinliğidir. Rusya Doğu Asya’nın önde gelen aktörlerinden Japonya ile ilişkilerini güçlendirerek Çin'in ekonomik ve politik etkisini dengeleme amacı gütmektedir. Öte yandan Moskova Tokyo ile ilişkilerini geliştirmekle, Japonya’ya coğrafi anlamda yakın olan doğu eyaletlerinin ekonomik gelişimini sağlamayı amaçlamaktadır.

Ancak Moskova ile Tokyo arasındaki bu olumlu hava Ukrayna krizi sonrasında yavaş yavaş dağılmaya başlamıştır. Rusya’nın Kırım’ı ilhakı sonrası Abe hükümetinin diğer G-8 ülkeleri gibi Rusya’yı kınayıp yaptırım uygulamaktan başka seçeneği kalmamıştır. Zira Rusya'nın ilhakına tavır almamanın hem müttefiki ABD ile olan ilişkilerini hem de G-8 içindeki konumunu tehlikeye düşürmesi muhtemeldir. Öte yandan bu hukuksuz harekete göz yummak gelecekte Çin'in tartışmalı Senkaku Adaları'na yönelik benzer bir davranışı söz konusu olduğunda Japonya'nın elini güçsüzleştirecektir. Vize düzenlemeleri ve çeşitli anlaşma görüşmelerinin askıya alınması dışında Abe, Ukrayna'ya 1.5 milyar dolarlık yardımda bulunulacağını belirtmiştir. ${ }^{41}$ Bununla birlikte Japon yaptırımları Batılı ülkelere kıyasla daha hafif kalmış ve bilhassa enerji sektörünü hedef almamıştır.

Fakat Rusya'nın Japonya’nın bu adımına tepkisi sert olmuştur. Nisan 2014'ten itibaren Rusya Hava Kuvvetleri'ne ait 6 adet stratejik bombardıman ve füze taşıyıcı 'lupolev Tu-95 uçağının Japon adaları (Hokkaydo ve Okinawa) üzerinde uçuş gerçekleştirmesi iki ülke arasında krize sebebiyet vermiştir. $^{42} 29$ Nisan 2014 tarihinde ise Japonya yaptırımların ikinci dilimini uygulayarak isimlerini

41 Ministery of Economy, Trade and Industry, March 2014, http://www.meti.go.jp/english/press/2014/0325_02.html (Erişim Tarihi 25 Ocak 2015).

42 “Минобороны России призвало Японию отменить санкции и сотрудничать” (Rusya Savunma Bakanlı̆̆ Japonya'ya yaptırımları durdurma ve işbirliği çağrısında bulundu), Nisan 21, 2014, http://russian.rt.com/ inotv/2014-04-21/Minoboroni-Rossii-prizvalo-YAponiyu-otmenit (Erişim Tarihi 15 Ocak 2015). 
açıklamadığı 23 Rusya vatandaşına geçici olarak vize verilmeyeceğini duyurmuştur. Ağustos 2014'de $A B D$ ve $A B$ 'nin Rusya'ya yönelik yeni yaptırımları sonrasında Japonya da içlerinde eski Ukrayna Cumhurbaşkanı Viktor Yanukoviç’in de bulunduğu 40 Rus vatandaşının ülkeye girişini yasaklamıştır. Bunlara ilaveten iki Kurım şirketine de -Feodosiya ve Çernomorneftegaz - yaptırım uygulamıştır. $\mathrm{Bu}$ yaptırımlara cevaben, Ağustos 2014’te Moskova bazı Japon vatandaşlarının Rusya'ya ziyaretini yasaklamıştır.

Temmuz 2014'te Ukrayna'daki Rus yanlısı ayrılıkçıların Malezya yolcu uçağını füzeyle vurarak düşürdüğü iddiası üzerine diğer ülkeler gibi Japonya da tepki göstermiş ve yaptırımları genişletmiştir. Yeni yaptırımlar Kırım'ın ilhakını destekleyen birey veya grupların Japonya'daki varlıklarının dondurulmasını, Kırım'dan ülkeye ithalatın sınırlandırılmasını, Rusya'da gerçekleştirilecek herhangi bir uluslararası projeye destek sağlanmamasını kapsamaktadır. ${ }^{43}$ Ayrıca Tokyo hükümeti Kırım’ın Rusya tarafından işgalini statükoyu güç uygulayarak değiştirme olarak değerlendirmiş ve bunun Asya bölgesi için de tehlike oluşturabilecek durum şeklinde yorumlamıştır. ${ }^{44}$

Moskova yönetimi bu tarihten sonra tutumunu sertleştirmiş, tartışmalı adalara yakın coğrafyada askeri tatbikatlar gerçekleştirmeye başlamıştır. 2014'te 1000'den fazla Rus askerinin, Rus Hava Kuvvetleri’nin ve Pasifik Donanması́nın katıldığı bu geniş kapsamlı tatbikat Abe tarafından "tek kelimeyle kabul edilemez" olarak yorumlanmıştır. ${ }^{45}$ Öte yandan Rus parlamentonun alt kanadı Duma'da temsil edilen Adaletli Rusya Partisi üyesi Oleh Miheev, Japonya’nın Kırım’ı Rusya toprağı olarak kabul edeceği zamana kadar Moskova-Tokyo arasındaki ihtilaflı adalar sorununun dondurulması önerisinde bulunmuştur. ${ }^{46}$ Ancak bu öneri kabul görmemiş̧ir. Son olarak 2015 'te Türkiye’nin ev sahipliğinde düzenlenen G-20 Zirvesi’nde Putin ile görüşen Abe, Kuril adaları meselesi için yeni bir toplantı gerçekleştirme talebinde bulunmuştur. ${ }^{47}$

\section{Neoklasik Realizm Perspektifinden Abe ve Putin'in Kuril Politikaları}

Abe ve Putin ikili ilişkilerin gelişiminin önündeki en büyük engel olan Kuril adaları sorununun çözümüne iki ülkeyi en fazla yaklaştıran siyasetçilerdir. Liderleri bu minvalde politikalar izlemeye iten unsurların incelenmesi, meselenin çözümüne yönelik ipuçlarını barındırması ve tarafların çözüm için atabileceği adımlara ilişkin fikir vermesi açısından önemlidir. Bu bağlamda 2013'ten itibaren Japonya ve Rusya'nın Kuril adaları meselesine ilişkin politikalarının, yapısal etkenlerin yanında birim seviyesindeki değişkenleri de değerlendirerek açıllayıcılık gücü yüksek bir analiz yapma

43 "Japan is stepping up sanctions against Russia amidst downing of Malaysia Airlines Flight MH17", New York Daily News, 28 Temmuz 2014, http://www.nydailynews.com/news/world/japan-stepping-sanctions-russia-article-1.1883094 (Erişim Tarihi 12 Ocak 2015).

44 “Япония расширит санкции в отношении России из-за ситуации на Украине” (Japonya Ukrayna sorunundan dolayı Rusya'ya yaptırımları genişletiyor), ITAR-Tass, 28 Temmuz 2014, http://www.vedomosti.ru/politics/ news/29515321/yaponiya-rasshirit-sankcii-v-otnoshenii-rossii (Erişim Tarihi 25 Ocak 2015).

45 “U.S. recognizes Japan's sovereignty over Russian-held isles: official”, The Japan Times, August 14, 2014, http://www. japantimes.co.jp/news/2014/08/14/national/u-s-recognizes-japans-sovereignty-over-russian-held-isles-official/ (Erişim Tarihi 25 Ocak 2015).

46 “Переговоры по Курилам хотят увязать с признанием присоединения Крыма” (Kuril görüşmeleri Kırım’ın ilhakının tanınmasıyla ilişkilendirilmeye çalışılıyor), Izvestia, 9 Nisan 2014, http://izvestia.ru/news/568876 (Erişim Tarihi 05 Ocak 2015).

47 Japan's Shinzo Abe calls for summit ith Russia's Vladimir Putin over Northern Territories Dispute, International Bussiness Times, January 4, 2016, http://www.ibtimes.com/japans-shinzo-abe-calls-summit-russias-vladimir-putinover-northern-territories-2247350 (Erişim Tarihi 10 Ocak 2016). 
amacındaki neoklasik realist teori çerçevesinde ele alınması uygun olacaktır. Daha önce de ifade edildiği gibi sistemsel koşullar dış politika koşullarını belirlemekle birlikte dış politika kararları iç dinamikler (devlet-toplum ilişkisi, farklı çıkar grupları, medya, sivil-asker ilişkileri, yaygın ideoloji, vs.) çerçevesinde hareket eden yöneticiler tarafından alınmaktadır. Dolayısıyla uluslararası ortamın yapısı kadar devlet içi faktörlerden kaynaklanan etmenlerin analize dâhil edilmesi daha kapsamlı ve açıklayıcı bir sonuç verecektir.

Örneğin Japon Başbakanı Koizumi’nin 2000'li yılların başında Pekin ile ilişkilerinde krize neden olan Yasukuni politikasının salt sistemler değişkenlerin incelenmesiyle anlaşılması mümkün değildir. ${ }^{48}$ Zira bu dönem Soğuk Savaş sonrası değişen uluslararası ortamın etkilerinin Doğu Asya’ya da yansıdığı, Çin'in yükselişinin bölgedeki güç dengelerini değiştirmeye başladığı ve Japonya'nın güvenliğinin tartışma konusu haline geldiği bir süreci beraberinde getirmiştir. Her ne kadar ABD'nin güvenlik şemsiyesi varlığını hissettirse de bu ortamda Çin ile ilişkilerde krize sebep olacak Yasukuni Tapınağı ziyaretlerinin Koizumi tarafından neden gerçekleştirildiğinin anlaşılması güçtür. İçyapısal özellikleri analizine dâhil eden Yew Mang Lai, ciddi bir halk desteğiyle göreve gelen Koizumi'nin bu politikasının Japon toplumunda bu dönemde artan milliyetçilikten ve Japonya'nın itaatkâr diplomasisinden (dogeza-gaiko) kaynaklanan hoşnutsuzluktan ayrı değerlendirilemeyeceğini ifade etmektedir. ${ }^{49}$ Toplumda yükselen milliyetçilik dalgasını arkasına alan Koizumi, tarihi ile barışık ve ondan güç alan, bölgesinde söz sahibi bir Japonya yaratma ve Çin ile daha realist ve eşitlikçi bir ilişki kurma hedefine vurgu yapmıştır. Lai Koizumi’nin Yasukuni politikasını Japonya'yı normalleştirme girişiminin bir parçası olarak yorumlamaktadır. Çin tehdidine karşı ABD ile ittifakın güçlendirilmesi ve anayasanın değiştirilerek askeri gücün artırılması gerektiği algısının oluşturulması amacı doğrultusunda, Yasukuni'nin sembolik ve siyasi değerinin kullanıldığını vurgulamaktadır. ${ }^{50}$ Neoklasik realizmin dış politikaları analiz etmede sağladığı bütüncül yaklaşım, ihtilaflı adalar sorununda Abe ve Putin'in politikalarının farklı değişkenleri içerecek biçimde kapsamlı olarak analiz edilmesine imkân vermektedir.

\section{Politikaları Şekillendiren Yapısal Faktörler}

Abe'nin göreve gelişinden itibaren gelişen Japonya-Rusya ilişkileri kapsamında tartışmalı Kuril adaları meselesine yönelik tarafların tutumlarını şekillendiren yapısal faktörlere bakıldığında Çin'in etkisi öncelikli olarak göze çarpmaktadır. Çin’in ekonomik atılımı ve buna bağlı olarak askeri gücünü geliştirmesi Asya-Pasifik bölgesinde güç dengelerinin değişmesine neden olmuştur. Buna paralel olarak ABD de bölgedeki askeri varlığını ve faaliyetlerini artırmıştır. Rusya ile Çin'in ABD'nin bu girişimlerine karşılık oluşturmayı amaçladığı yeni bölgesel ortak güvenlik sistemi planı ve Doğu Çin Denizi'nde gerçekleştirilen ortak askeri tatbikatlar Japonya için endişe kaynağıdır. Japonya ile Çin arasındaki toprak ve deniz sınır anlaşmazlıkları ile Çin'in bölgede artan nüfuzu sebebiyle Rusya ile ilişkileri normalleştirmek Japonya için büyük ehemmiyet arz etmektedir. Rusya ile ilişkilerdeki gerginlik, bölgede kendini hissettiren Rusya-Çin ortaklığını daha da güçlendirerek bölgesel güç dengesinin ve kapasite dağılımının Japonya'nın aleyhinde şekillenmesine sebebiyet verecektir.

48 20. yüzyılın ilk yarısındaki savaşlarda hayatını kaybeden yaklaşık 2,5 milyon Japon askeri (Tokyo Uluslararası Askerî Mahkemesinde yargılanıp A-sınıfı savaş suçlusu ilan edilmiş olanlar da dâhil ) adına yaptırılan ve bazı çevrelerce Japon militarizmiyle özdeşleştirilen tapınağa yapılan ziyareti nitelemek için kullanılmaktadır.

49 Yew Meng Lai, "Nationalism and Power Politics in Japan's Relations with China”, University of Warwick, Department of Politics and International Studies, December 2008, s.189.

50 Ibid. 
Rusya açısından Kuzeydoğu Asya bölgesinde Kuzey Kore’nin nükleer politikası, Kuzey ve Güney Kore arasındaki sorunlar ve Çin'in hegemonik yaklaşımları gibi güvenlik sorunlarının mevcudiyeti, Moskova'nın bölgeye yönelik politikalarında şekillendirici rol oynamaktadır. Tüm bu faktörlerin yanı sıra ABD’nin Asya'ya yöneliş (pivot to Asia) stratejisi Rusya'nın son yıllarda askeri gücünü bu bölgeye kaydırmasına neden olmuştur. Rusya ve Çin’in bölgedeki askeri tatbikatları ile ABD'nin Japonya ve Güney Kore ile ortak askeri tatbikatları bölgedeki güç rekabetini gözler önüne sermektedir. Bu bakımdan ABD'nin Asya-Pasifik'teki başlıca müttefiklerinden Japonya ile ilişkilerin iyileştirilmesi hem ABD'nin hem de Çin'in gücünü dengelemek açısından ehemmiyet arz etmektedir. Dolayısıyla ikili ilişkilerin geliştirmesinin önünde temel engel olarak görülen tartışmalı adalar meselesinin çözümü önemlidir. Söz konusu göreli güç değişimi ve uluslararası sistemin etkilerinin yanı sıra aracı değişken olarak kullanılan iç faktörler de Kuril meselesine ilişkin tarafların politika tercihlerini etkilemektedir.

\section{Politikaları Şekillendiren iç Faktörler}

Aracı değişkenlerin neleri kapsadığı hususunda literatürde bir uzlaşı bulunmamakla birlikte, "liderlerin algılamaları" ve "devletlerin kendilerine ait içyapılarında yer alan özellikler" olmak üzere çoğunlukla iki temel aracı değişkenin kullanılması yoluna başvurulmaktadır. ${ }^{51}$ Bu bağlamda 20062007 yılları arasındaki başbakanlık görevi başarısızlıkla sonuçlanan ve istifa etmek durumunda kalan Abe, Japon halkının temel beklentisinin ekonomik durgunluğun aşılması olduğunun farkındadır. Bu amaçla yürürlüğe koyduğu reformlar ve aldığı önlemlerin yanı sıra ticaretin artırılması ekonomiyi canlandırmak adına önem taşımaktadır. 2014 yılında Japonya ile Rusya arasındaki ticaret hacmi 18,2 milyar dolarken Çin ile Rusya arasındaki ticaret hacmi 52 milyar dolardır. ${ }^{52}$ İhracattaki durgunluk göz önünde tutularak Rusya'nın Japon araba, motor ve elektronik ekipmanları için önemli bir pazar olduğu belirtilmelidir. Ancak Rusya'ya yakınlaşma esas itibariyle kapatılan nükleer reaktörler nedeniyle enerjide yaşanan sıkıntıya aşmak açısından elzemdir. Japonya'nın yaptırım kararı öncesinde Japonya'nın ihtiyaç duyduğu doğalgazın $\% 9,8$ 'i petrolün ise \%5'i Rusya tarafindan karşılanmaktaydı. ${ }^{53}$ Tokyo hükümeti bu oranların artırılmasını hedeflemektedir. Örneğin görüşmeleri süren Sahalin Adası'ndan (Rusya) Hokkaido Adası́na (Japonya) uzanan bir doğalgaz boru hattının inşası durumunda Rusyánın Japonya’ya yıllık 20 milyar metreküp doğalgaz ihraç edeceği düşünülmektedir ki bu da Japonya'nın yıllık ithalatının \%17'sine eşittir. ${ }^{54}$ Öte yandan ekonomisi büyük oranda dış ticarete dayanan bir ülkede iş çevrelerinin de dış politika üzerinde etki sahibi olması kaçınılmazdır. Zakai (iş dünyası) ihracatın artırılması açısından dış pazarların çeşitlendirilmesi ve ticari ilişkilerin teşviki hususunda karar alıcılara baskı yapmaktadır.

Abe ülkesini kronik durgunluktan kurtaran ve sürüncemedeki Kuril sorununu çözen lider olmak arzusundadır. Zira 2001-2006 yılları arasında başbakanlık görevini yürüten Juniçiro Koizumi’den sonra Japonya'da ardı ardına başbakan istifaları yaşanmış ve siyasi anlamda istikrar sağlanamamıştır. Japon halkı Koizumi’den sonra ikinci bir karizmatik lider arayışındadır ki Koizumi de bu sorunun

51 Rose, "Neoclassical Realism”, s.160.

52 “Russia's 10 Largest Trading Partners in 2014, How Many In The Correct Order Can You Name?”, Russia Insider, September 23, 2014, http://russia-insider.com/en/politics_business/2014/11/04/02-12-09pm/russias_10_largest_ trading_partners_2014_how_many_correct (Erişim Tarihi 26 Ocak 2015).

53 Clint Richards, “Russia and Japan's pipeline dilemma”, The Diplomat, October 15, 2014, http://thediplomat. com/2014/10/russia-and-japans-pipeline-dilemma/ (Erişim Tarihi 26 Ocak 2015).

54 Ibid. 
çözümü için pek çok defa Putin ile görüşmüş ancak bir sonuca ulaşılamamıştır. Koizumi’nin yaptığı gibi Abe de dış politikadaki hareket alanını genişletmek amacıyla Dışişleri Bakanlığı́nın güçlü bürokrasisini aşmaya çalışmış ve devletin çeşitli kademelerinde görev alacak bürokratların seçimi için yeni bir Personel İşleri Ofisi kurmuştur.

Abe, Japonya'da pek çok özel yapılanmanın canlı tutmaya ve ulusal bilinç yaratmaya çalıştığı Kuril Adaları sorununu çözüme kavuşturan lider olmak istemektedir. Dört adanın Rusya'nın kontrolünde olması, "İkinci Dünya Savaşı yenilgisini ve Japon topraklarının zorla ellerinde alındığını hatırlattığından” Japon halkı için sembolik bir öneme sahiptir. ${ }^{55}$ Kaliforniya Üniversitesi’nden Dr. Tsuyoshi Hasegawa Japonya açısından Kuzey Toprakları meselesinin psikolojik bir boyutunun bulunduğunun, Hiroşima'ya atılan atom bombasının ve Kuzey Toprakları’nın Rusya tarafından işgal edilmesinin Japonlarda ciddi bir mağduriyet duygusu yarattığının altını çizmektedir. ${ }^{56}$ Dolayısıyla adaların tekrar Japonya’nın kontrolüne geçmesi Japon halkı için büyük önem taşımaktadır. Bunu sağlaması durumunda Abe'nin yeni seçimlerde elinin oldukça güçlü olacağını söylemek yanlış olmayacaktır. Kuzey Toprakları olmadan Japonyánın bir bütün olamayacağı ve Japonların da tam anlamıyla vatanlarının sahibi olamayacakları düşüncesi Japon toplumsal hafızasında yer etmiştir. Bu sebeple Japon liderler adalar meselesine karşı ilgisiz dahi olsalar Japon iddialarını savunmanın seçimlerde kendileri için avantaj teşkil edeceğini bilmektedirler. ${ }^{57}$

Muhafazakar ve milliyetçi çizgideki Abe için milliyetçi Japonlar nezdinde gurur meselesi haline gelen bu sorunun çözülerek adaların Japon topraklarına dahil edilmesi ciddi bir popülarite unsuru olacaktır. Ancak bu durum aynı zamanda da birtakım tavizlerde bulunarak sorunun çözümünü kolaylaştırmayı engellemektedir. Masadaki en muhtemel çözüm olan iki adanın Japonya'ya verilip diğer ikisinin ise Rusya'da kalması önerisi iktidardaki Liberal Demokratik Parti içerisindeki şahin kanadı tatmin etmemektedir. Dolayısıyla Abe partisinin bazı üyelerinin baskısıyla karşı karşıya kalmaktadır. Bununla birlikte 2012'de Tokyo hükümeti tarafından gerçekleştirilen bir araştırma, Rusya'yı güvenilir bir komşu olarak görmemesine rağmen Japon halkı, genel olarak esnek bir çözümü desteklediğini gözler önüne sermektedir. ${ }^{58}$ Büyük çoğunluğun pasifist eğilimli olan Japon halkı anlaşmazlıkların barışçıl çözümünü desteklemekte ve ekonomik durumun düzelmesini temel öncelik olarak görmektedir ki bu görüş Abe’nin dış politikasına da yansımaktadır.

Meseleye Rus iç dinamikleri göz önüne alınarak bakıldığında, Japonya'ya benzer şekilde ekonomik gidişatın temel şekillendirici faktörlerden olduğu görülmektedir. Haziran 2014'ten itibaren düşüş gösteren petrol fiyatlarının yılın sonuna doğru daha da aşağı inmesi, dünyanın en büyük enerji ihracatçılarından Rusya'nın ekonomisini tehdit etmeye başlamıştır. Doğalgaz ihracatında Batı Avrupa'nın önemli yer tuttuğu Rusya, yaptırımlar sonrası ticaret ortaklarını genişletmek amacıyla Kuzeydoğu Asya bölgesine yönelmiş ${ }^{59}$ ve Çin ile Mayıs 2014'te 400 milyar dolarlık büyük bir doğalgaz anlaşması imzalamışırı. Kuzeydoğu Asya’ ya bu yöneliş, yaşanan gerginliklere ve mevcut yaptırımlara

55 Brad Williams, Hokkaido-Sahalin Subnational Government Relations: Opportunities and Limits of Kankyo Seibi, Yayınlanmış Doktora Tezi, School of Languages, Cultures and Linguistics, Monash University, 2003, s.72.

56 Tsuyoshi Hasegawa, “Japanese Policy Towards Russia: Principles, Contradictions and Prospects", Takayuki Ito ve Shinichiro Tabata (der.), Between Disintegration and Reintegration, Hokkaido, Hokkaido University Press, 1994, s.333.

57 Masato Kimura and David A. Welch, “Specifying 'Interests': Japan's Claim to the Northern Territories and its Implications for International Relations Theory”, International Studies Quarterly, No.42, 1998, s.238.

58 Public Opinion Poll on the Northern Territories Issue, Cabinet Office of Japan, November 2013, http://www.cao. go.jp/en/news/2013/index.html (Erişim Tarihi 27 Ocak 2015).

59 Rusya'nın Kuzey Doğu Asya’ya yönelişi ile ilgili detaylı bilgi için bkz. Tuğçe Varol Sevim, "Rus Dış Enerji Politikası ve Yeni Hedef Kuzey Doğu Asya”, Uluslararası İlişkiler, Cilt 11, Sayı 41, Bahar 2014, s.87-108. 
rağmen Moskova'nın Tokyo'ya Sahalin Adası'ndan (Rusya) Hokkaido Adası'na (Japonya) uzanan bir doğalgaz boru hattı inşa etme görüşmelerine yeniden başlama teklifinde bulunmasının temel sebebidir. Bu boru hattının inşası durumunda Rusya'nın Japonya'ya yıllık 20 milyar metreküp doğalgaz ihraç edeceği tahmin edilmektedir. ${ }^{60}$

Ülkenin içinde bulunduğu ekonomik krize kısa vadede çözüm bulunamaması Putin’in halk nezdindeki popülaritesini olumsuz etkileyeceği tahmin edilebilir. Bu noktada 1998 ekonomik krizinin Yeltsin'i koltuğunu Putin'e devretmek zorunda bıraktığı hatırlanmalıdır. Putin sahip olduğu popülaritesini ülkenin enerji rezervlerini kullanarak ekonomiyi düzeltmesine ve ekonomik refahı artırmasına borçludur. Russia in Global Affairs Dergisi editörü Fyodor Lukyanov, "krizin derinleşmesinin ve uzamasının eninde sonunda Putin'i etkileyeceğini” dile getirmektedir. ${ }^{61}$ Ekonomiyi yeniden canlandırmak amacıyla Rus petrol ve doğalgazı için yeni pazar arayışında olan Putin Japonya ile ilişkilerini bu amaç doğrultusunda yürütmektedir.

Bununla birlikte Ukrayna krizinin Rusya'da milliyetçiliği tetiklemesi Putin’i milliyetçi grupların taleplerini göz önünde bulundurmaya itmektedir. Bu sebeple adalar meselesinde Rusya'nın vereceği tavizlerin sınırlı olduğunu söylemek yanlış olmayacaktır. Ayrıca 2009'da All-Russian Public Opinion Research tarafından gerçekleştirilen bir araştırmaya göre Rus halkının \%89'u adaların Japonya'ya iadesine karşı çıkmaktadır. ${ }^{62} 2010$ 'da aynı kurum tarafından gerçekleştirilen ankette katılımcıların \%79'u Rusya'nın dört adayı da elinde tutmaya devam etmesi ve görüşmelere son verilmesi gerektiğini ifade etmiştir. ${ }^{63} \mathrm{Bu}$ sonuç, topraklardan taviz vermenin ülke açısından bir zayıflık göstergesi olduğu düşüncesinin Rusya’da -özellikle Putin döneminde- yaygın oluşuyla açıklanabilir.

Bununla birlikte Kasım 2005'te Hokkaido Gazetesi tarafindan yapılan ankete göre Iturup Adası'ndaki halkın \% 80'i ile Kunaşir Adası'ndaki halkın \% 63'ü adaların Japonya'ya iadesine karşıyken Şikotan halkının \%50'si iadeye olumlu bakmaktadır. ${ }^{64} \mathrm{Bu}$ araştırmalardan yola çıarak Şikotan ve Habornai adalarının Japonya' ya iadesinin olası göründüğü ancak Rus halkının bu duruma tepkisiz kalmayacağını söylemek mümkündür. Bu da anlaşmazlığın çözümüyle ilgili Putin’in işini zorlaştırmaktadır.

Neoklasik realist çerçevede ele alınan yapısal faktörler Japonya ve Rusya için benzerlik göstermektedir. Çin'in Doğu Asya bölgesinde artan nüfuzu, bu iki ülkeyi bölgesel güç dengesi ve kapasite dağılımını konusunda avantaj sağlama amaçlı hareket etmeye ve yakınlaşmaya itmektedir. İç faktörler hususunda da benzerlikler olmakla birlikte (ekonomik gerekçeler, artan milliyetçilik, halk nezdinde itibar gibi) bu etmenler farklı siyasi ve toplumsal yapılar sebebiyle dış politikaya aynı şekilde yansımamaktadır.

60 Richards, "Russia and Japan's pipeline dilemma".

61 Jim Maceda, "Russia's Economic Crisis: Can Putin save Russia and himself?", NBC News, January 2, 2015, http://www. nbcnews.com/news/world/russias-economic-crisis-can-putin-save-russia-himself-n275496 (Erişim Tarihi 29 Ocak 2015).

62 Sergey Borisov, "ROAR:Trusting relationship unlikely to solve main problem for Russia-Japan”, Russia Today, September 8, 2009.

63 President and the Kurils, Press release No.1327, Russian Public Opinion Research Center, http://wciom.com/index. php?id=61\&uid=165 (Erişim Tarihi 29 Ocak 2015).

64 "Northern Territories/Kuril Islands", http://www.globalsecurity.org/military/world/war/kuril.htm (Erişim Tarihi 29 Ocak 2015). 


\section{Sonuç}

Kuril Adaları sorunu İkinci Dünya Savaşı́ndan sonra Rusya-Japonya arasındaki ilişkileri belirleyen en önemli konudur. İki ülke arasında bu sorundan ötürü herhangi bir barış antlaşmasının imzalanmamış olması ve adalarla ilgili her iki tarafın tutum ve söylemleri ilişkilerde zaman zaman gerilim yaşanmasına yol açmaktadır. Yıllardır bu sorunun sürüncemede kalmasının temel sebebi Kuril Adaları'nın taraflar açısından ekonomik, politik ve sembolik öneme sahip olmasıdır.

Aralık 2012'de göreve gelen Japonya Başbakanı Şinzo Abe'nin çabalarıyla ikili ilişkilerde olumlu gelişmeler yaşanmış ancak Ukrayna krizi ve Kırım’ın Rusya tarafından işgali, ilişkilerde uzun yıllar sonra yakalanan bu ılımlı havanın bozulmasına sebep olmuştur. Japonya'nın Rusya'ya karşı ekonomik ve politik yaptırım uygulaması sonucu bozulan ilişkiler, Kuril Adaları sorununun diplomatikçözümüne yönelik planların rafa kalkmasına yol açmıştır.

Japonya'nın Batı ile müttefiklik ilişkisi ve ABD’nin Japonya'nın güvenliği için garantör devlet statüsü Tokyo'nun söz konusu yaptırımları uygulamasındaki temel gerekçelerdir. Ayrıca Kırım’ın Rusya tarafından güç kullanılarak ilhak edilmesine verilecek tepki Çin'in tartışmalı Senkaku/Diaoyu Adaları́nda benzer bir girişimde bulunmasının önüne geçilmesi açısından önem arz etmektedir. Rusya, Japon hava sahasının ihlali ve tartışmalı adalarda düzenlenen askeri tatbikat ile bu yaptırımlara sert tepki vermiş ve ilişkiler yeniden bozulmaya başlamıştır.

Ancak Kuzeydoğu Asya'daki güç mücadelesiyle biçimlenen konjonktürel durumun yanı sıra iç faktörler iki ülkeyi ilişkileri geliştirmeye ve Kuril sorununa çözüm aramaya itmektedir. Siyasi geleceği bir ölçüde Japon halkının ekonomik durgunluğu aşma beklentisini karşılamasına bağlı olan Abe, hem ticari ilişkileri geliştirmek hem de enerjide yaşanan sıkıntıyı gidermek amacıyla Rusya'ya yakınlaşmaktadır. Ayrıca hırslı kişiliği onu karizmatik lider imajını güçlendirmek amacıyla Kuril sorununu çözme amaçlı çalışmalara itmektedir. Japon toplumunda milli mesele addedilen Kuzey Toprakları sorununun tatmin edici çözümü milliyet çizgideki Abe'nin siyasi kariyeri açısından da ehemmiyet arz etmektedir.

Rusya ise petrol fiyatlarının düşüşü sebebiyle içinde bulunduğu ekonomik krizden çıkmak amacıyla kendisine yaptırım uygulayan Batı’ ya karşı Doğu' ya yönelmiştir. Bu sebeple önemli bir enerji ithalatçısı olan Japonya ideal bir ticari partner konumundadır. Zira bu ekonomik krizin derinleşmesi durumunda uzun vadede Putin'in halk nezdindeki popülaritesinin azalması muhtemeldir. Ayrıca bu kriz Rusya'nın askeri yatırım ve faaliyetlerini de olumsuz etkileyecektir ki Asya-Pasifik bölgesindeki güç rekabeti göz önüne alındığında bu durum Putin Rusya'sı için ciddi bir sorun teşkil etmektedir.

Kuril sorununun çözümünde tarafların üzerinde uzlaşmaya en yakın olduğu çözüm yolu Habornai ve Şikotan adalarının Japonya'ya verilmesi, bunun karşılığında Tokyo'nun diğer iki ada üzerindeki Rus egemenliğini tanıyıp hak iddiasından vazgeçmesi idi. Bu çözümün bugün hala geçerliliğini koruduğu söylenebilir. Neoklasik realizm çerçevesinde ele alınan yapısal ve iç faktörler, çözüm görüşmelerinde tarafların pazarlık marjlarının belirlenmesinde de söz sahibidir. Hangi tarafın elinin daha güçlü olduğu, hangi tarafin tavize daha yatkın bulunduğu, bu amaçla belirlenecek değişkenler aracılığıyla yapılacak karşılaştırmalı analizle ortaya konulabilir. Neoklasik realizm kapsamında genel kabul görmüş ve sabit olarak kullanılan değişkenlerin bulunmadığından bu pazarlık gücünü ölçmede kullanılacak değişkenler araştırmacı tarafından belirlenecektir. Dolayısıyla neoklasik realist yaklaşım bu doğrultudaki araştırmalara faydalı bir analitik zemin oluşturabilir. 


\section{Kaynakça}

Aydın, Mustafa. "Uluslararası İlişkilerin Gerçekçi Teorisi: Kökeni, Kapsamı, Kritiğì, Uluslararası İlişkiler, Cilt 1, Sayı 1, Bahar 2004, s.33-60

Borders, Menas. "Claim and counter-claim in the Kuril islands dispute", MENAS, April 2011, http://www. menas.co.uk/documents/menas-kurils.pdf (Erişim Tarihi 22 Ocak 2015).

Bukh, Alexander. “'Takeshima' and 'Northern Territories' in Japan's Nationalism”, China Policy Institute, 16 October 2014, http://blogs.nottingham.ac.uk/chinapolicyinstitute/2014/10/16/takeshima-andnorthern-territories-in-japans-nationalism/ (Erişim Tarihi 20 Ocak 2015).

Christensen, Thomas J. Useful Adversaries: Grand Strategy, Domestic Mobilization, and Sino-American Conflict, 1947-1958, Princeton, Princeton University Press, 1996.

Clark, Gregory. "Northern territory dispute highlights flawed diplomacy", www.japantimes.co.jp/ opinion/2005/03/24/commentary/northern-territories-dispute-highlights-flawed-diplomacy/\#. VOGpc1xjDwI (Erişim Tarihi 16 Ocak 2015).

Gorenburg, Dmitry. “The Southern Kuril Island Dispute”, PONARS Eurasia Policy Memo, No. 226, September 2012.

Hasegawa, Tsuyoshi. “Japanese Policy Towards Russia: Principles, Contradictions and Prospects", Takayuki Ito ve Shinichiro Tabata (der.), Between Disintegration and Reintegration, Hokkaido, Hokkaido University Press, 1994, s.329-368.

"Japan concerned over Russia’s Military buildup on disputed Kuril Islands", Eurasia Review News, Mart 02, 2011, http://www.eurasiareview.com/02032011-japan-concerned-over-russias-military-buildup-on-disputedkuril-islands/ (Erişim Tarihi 15 Ocak 2015).

"Japan is stepping up sanctions against Russia amidst downing of Malaysia Airlines Flight MH17", New York Daily News, Temmuz 28, 2014, www.nydailynews.com/news/world/japan-stepping-sanctions-russiaarticle-1.1883094 (Erişim Tarihi 12 Ocak 2015).

"Japan-US treaty does not apply to Kuril Islands", China Daily, March 11, 2010, http://www.chinadaily.com.cn/ world/2010-11/03/content_11497642.htm (Erişim Tarihi 24 Ocak 2015).

“Japanese Ambassador returns to Moscow”, Kyodo News, Kasım 8, 2010, http://www.japantimes.co.jp/ news/2010/11/08/national/japanese-ambassador-returns-to-moscow/\#.VOG8C1xjDwI (Erişim Tarihi 12 Ocak 2015).

“Japanese Minister says French Mistral deal with Russia can affect Japan's security”, Sputnik News, July 27, 2014, http://sputniknews.com/military/20140729/191437899.html (Erişim Tarihi 25 Ocak 2015).

Joint Declaration by the Union of Soviet Socialist Republics and Japan, October 19, 1956, http://www.ioc.utokyo.ac.jp/ worldjpn/documents/texts/docs/19561019.D1E.html (Erişim Tarihi 20 Ocak 2015).

Kimura, Hiroshi. Japanese-Russian Relations under Brezhnev and Andropov, Cilt 1, Armonk, New York, Sharpe, 2000.

Kimura, Hiroshi. The Kurillian Knot: A History of Japanese-Russian Border Relations, California, Stanford University Press, 2008.

Kimura, Masato and David A. Welch. "Specifying 'Interests': Japan's Claim to the Northern Territories and its Implications for International Relations Theory”, International Studies Quarterly, Cilt 42, No.2, Haziran 1998, s.213-244.

Koshkin, Anatoliy. "Правая история: Почему нет мирного договора с Японией” (Gerçek Tarih: Neden Japonya ile barış antlaşması yok?), 20 Ekim 2014 (Erişim Tarihi 10 Ocak 2015).

Koshkin, Anatoliy. "Россия и Япония: возможен ки компромисс о Курилах?” (Rusya ve Japonya: Kuril Adalarında Uzlaşma mümkün mü?), Азия и Африка сегодня (Asya ve Afrika Bugün), Kasım 2008.

Litovkin, Viktora. "Курильская военная аномалия”, Nezavisimaya Gazeta, 13 Ekim 2011, http://nvo.ng.ru/ nvo/2011-10-13/1_kurily.html (Erişim Tarihi 24 Ocak 2015). 
Maceda, Jim. "Russia’s Economic Crisis: Can Putin save Russia and himself?", NBC News, 2 January 2015, http://www.nbcnews.com/news/world/russias-economic-crisis-can-putin-save-russia-himself-n275496 (Erişim Tarihi 29 Ocak 2015).

Miller, J. Berkshire. "Japan's Russia policy is in shambles over Ukraine, Kurils", The Asahi Shimbun, September 26, 2014, http://ajw.asahi.com/article/forum/politics_and_economy/east_asia/AJ201409260030 (Erişim Tarihi 25 Ocak 2015).

Ministery of Economy, Trade and Industry, March 2014, http://www.meti.go.jp/english/press/2014/0325_02. html (Erişim Tarihi 25 Ocak 2015).

"Минобороны России призвало Японию отменить санкции и сотрудничать“ (Rusya Savunma Bakanlı̆ğ Japonya'ya yaptırımları durdurma ve işbirliği çağrısında bulundu), Nisan 21, 2014, http://russian.rt.com/ inotv/2014-04-21/Minoboroni-Rossii-prizvalo-YAponiyu-otmenit (Erişim Tarihi 15 Ocak 2015).

Moscow Declaration on Establishing a Creative Partnership between Japan and the Russian Federation, 13, November 1998, http://www.mofa.go.jp/region/europe/russia/territory/edition01/moscow.html (Erişim Tarihi 22 Ocak 2015).

"Northern Territories/Kuril Islands", http://www.globalsecurity.org/military/world/war/kuril.htm (Erişim Tarihi 29 Ocak 2015).

Памятная записка Правительства СССР Правительству Японии от 27 января 1960 года (SSCN'nin Japonya' ya 27 Ocak 1960 tarihlidiplomatikmuhtırası), http://www.ru.emb-japan.go.jp/RELATIONSHIP/ MAINDOCS/normal.html\#4 (Erişim Tarihi 10 Ocak 2015).

“Переговоры по Курихам хотят увязать с признанием присоединения Крыма”, Izvestia, Nisan 9, 2014, http://izvestia.ru/news/568876 (Erişim Tarihi 05 Ocak 2015).

Public Opinion Poll on the Northern Territories Issue, Cabinet Office of Japan, November 2013, http://www. cao.go.jp/en/news/2013/index.html (Erişim Tarihi 27 Ocak 2015).

Richards, Clint. "Russia and Japan's pipeline dilemma”, The Diplomat, October 15, 2014, http://thediplomat. com/2014/10/russia-and-japans-pipeline-dilemma/ (Erişim Tarihi 26 Ocak 2015).

Rose, Gideon. "Neoclassical Realism and Theories of Foreign Policy", World Politics, Cilt 51, No.1, October 1998, s.144-172.

"Russia to deploy modern missile defense systems on disputed Kuril Islands", RIA Novosti, February 15, 2011, www.eurasiareview.com/15022011-russia-to-deploy-modern-missile-defense-systems-on-disputed-kurilislands/ (Erişim Tarihi 12 Ocak 2015).

“Russia's 10 Largest Trading Partners in 2014, How Many In The Correct Order Can You Name?”, Russia Insider, September 23, 2014, http://russia-insider.com/en/politics_business/2014/11/04/02-12-09pm/ russias_10_largest_trading_partners_2014_how_many_correct (Ërişim Tarihi 26 Ocak 2015).

“Российскую Аивизию на Курияах оснастят новейшим вооружением” (Kuril'deki Rusya tümeni modern silahlarla teçhiz edilecek), Vesti, Şubat 20, 2011, http://www.vesti.ru/doc.html?id=430088 (Erişim Tarihi 24 Ocak 2015).

“Россия застроит Южные Курилы военными объектами к 2016 году” (Rusya Güney Kuril'de 2016'ya kadar askeritesislerinşaetmeyiamaçliyor),Nisan 18,2014,http://ria.ru/defense_safety/20140418/1004490329. html (Erişim tarihi 17 Ocak 2015).

Schoenbaum, Thomas. Peace in Northeast Asia: Resolving Japan's Territorial and Maritime Disputes with China, Korea and the Russian Federation, Cheltenham, Edward Elgar Publishing, 2008.

Schweller, Randall L. Deadly Imbalances: Tripolarity and Hitlers Strategy of World Conquest, New York, Columbia University Press, 1998.

Sevim, Tuğçe Varol. "Rus Dış Enerji Politikası ve Yeni Hedef Kuzey Doğu Asya”, Uluslararası İişkiler, Cilt 11, Sayı 41, Bahar 2014, s.87-108.

The Geneva Conventions of 12 August 1949, https://www.icrc.org/eng/assets/files/publications/icrc-0020173.pdf (Erişim Tarihi 20 Ocak 2015). 
The Treaty of Portsmouth, 1905, https://history.state.gov/milestones/1899-1913/portsmouth-treaty (Erişim Tarihi 9 Ocak 2015).

Tokyo Declaration on Japan-Russia Relations, October 13, 1993, http://www.mofa.go.jp/region/n-america/ us/q\&a/declaration.html (Erişim Tarihi 22 Ocak 2015).

Treaty of Peace with Japan, San Francisco, September 8, 1951, https://treaties.un.org/doc/Publication/UNTS/ Volume\%20136/volume-136-I-1832-English.pdf (Erişim Tarihi 15 Ocak 2015).

"U.S. recognizes Japan's sovereignty over Russian-held isles: official", The Japan Times, August 14, 2014, http:// www.japantimes.co.jp/news/2014/08/14/national/u-s-recognizes-japans-sovereignty-over-russian-heldisles-official/ (Erişim Tarihi 25 Ocak 2015).

Williams, Brad. Hokkaido-Sahalin Subnational Government Relations: Opportunities and Limits of Kankyo Seibi, Yayınlanmış Doktora Tezi, School of Languages, Cultures and Linguistics, Monash University, August 2003.

Williams, Brad. Resolving the Russo-Japanese Territorial Dispute: Hokkaido-Sahalin Relations, NewYork, Routledge, 2007.

Wohlforth, William. The Elusive Balance: Power and Perceptions During the Cold War, Ithaca, Cornell University Press, 1993.

Zakaria, Fareed. From Wealth to Power: The Unusual Origins of America's World Role, Princeton, Princeton University Press, 1998.

“Япония расширит санкции в отношении России из-за ситуации на Украине” (Japonya Ukrayna sorunundan dolayı Rusya' ya yaptırımları genişletiyor), ITAR-Tass, 28 Temmuz 2014, www.vedomosti.ru/politics/ news/29515321/yaponiya-rasshirit-sankcii-v-otnoshenii-rossii (Erişim Tarihi 25 Ocak 2015).

102. Memorandum of a Conversation, Secretary Dulles' Residence, Foreign Relations of the United States, 1955-1957, Volume XXIII, Part 1, Japan, Document 102, Washington, 7 Eylül 1956, http://history.state. gov/historicaldocuments/frus1955-57v23p1/d102 (Erişim Tarihi 19 Ocak 2015). 
Copyright of International Relations / Uluslararasi Iliskiler is the property of International Relations Council and its content may not be copied or emailed to multiple sites or posted to a listserv without the copyright holder's express written permission. However, users may print, download, or email articles for individual use. 